\title{
Ecohydrological characterization of the Nyando wetland, Lake Victoria, Kenya: A State of System (SoS) analysis
}

\author{
P. S. Khisa ${ }^{1,2,3}$, S. Uhlenbrook ${ }^{2,3}$, A. A. van Dam $^{2}$, J. Wenninger ${ }^{2,3}$, A. van Griensven ${ }^{2}$ and \\ M. Abira ${ }^{1}$ \\ ${ }^{1}$ Water Resources Management Authority, Lake Victoria South Catchment Area, P.O Box 666-40100 Kisumu, Kenya. \\ ${ }^{2}$ UNESCO-IHE Institute for Water Education, P.O. Box 3015, Delft, The Netherlands. \\ ${ }^{3}$ Delft University of Technology, Water Resources Section, P.O. Box 5048, Delft, The Netherlands.
}

Accepted 12 May, 2013

\begin{abstract}
Lake Victoria floodplain wetlands have a complex hydrological setting characterized by transition from a terrestrial to an aquatic environment. A state-of-system (SoS) analysis was carried out in a papyrus dominated wetland in the Nyando River Delta, on the eastern shores of Lake Victoria, Kenya, to characterize and provide data for detailed ecohydrological studies. The objectives of the study were to: (1) determine the spatio- temporal changes in the wetland evolution and (2) analyze the main hydrological factors that have influenced wetland evolution. Multi-temporal dry-season Landsat MSS, Landsat TM and Landsat ETM+ imagery covering Nyando Wetland and its surrounding area were processed and analyzed to generate time series polygon and polyline maps of the wetland and river. Results show that the wetland increased in size from 5,925 ha in 1950 to 9,925 ha in 1973, and declined to 4,527 ha in 2008. In the last 60 years, Nyando River has migrated in a general eastward direction. Time series hydrological data (1950-2009) were statistically tested for homogeneity using the Spearman's rank test for linear trends, Pettit test and Standard Normal Homogeneity test (SNHT) for change point analysis, and split-record tests performed for variance (F-test) and mean (t-test). In addition, data were analyzed using descriptive statistics and frequency analyses. Statistical test results show that the hydrological data series were homogeneous. Results of change point analyses indicate that total annual rainfall in Nyando declined in 1979, while the mean annual discharge for Nyando River and Lake Victoria levels had significant upward shifts in 1961. The decadal mean discharges varied significantly over time and increased by $80 \%$ from $11.45 \mathrm{~m}^{3} / \mathrm{s}$ observed in the 1950-1961 subset, reducing by 11.4 and $21.9 \%$ in the next two decadal sub-sets, before rising by $35.0 \%$ in 1990 s and dropping by $24.0 \%$ in the last decade. The decadal mean annual lake levels increased from 1134.0 to $1135.43 \mathrm{~m}$ in the 1951-1961 and 1962-1972 and remained above the longterm mean of $1135.0 \mathrm{~m}$ for 43 years since 1962 before dropping drastically by $1.4 \mathrm{~m}$ to an average of $1134 \mathrm{~m} /$ year in 2005-2009. The highest recorded lake level at Kisumu Station was $1136.2 \mathrm{~m}$ in 1964 after increasing by $2.5 \mathrm{~m}$ from 1961. Discharge data exhibit trimodal seasonal patterns, while the lake levels had two peaks. The lake levels are more sensitive to direct lake rainfall. Changes in the Nyando wetland area are linked to the seasonal and episodic flood and drought events coupled with anthropogenic activities (regulation of lake levels, modification of river including cut-off meanders, river training and construction of dykes, drainage of wetland for cultivation, settlement and livestock grazing, abstraction of water for irrigation). A combination of these hydrological and human factors is the main cause of the Nyando Wetland evolution. If the land use trend continues unabated, then the increase in papyrus losses will pose a big challenge to the ecological functioning of the wetland and its support to sustaining community livelihoods.
\end{abstract}

Key words: Nyando Wetland, River, ecohydrology, Lake Victoria. 


\section{INTRODUCTION}

Estuarine wetlands and floodplain wetlands near large lakes are characterized by complex interactions between vegetation types, surface water fluxes and pore water movements, and are very sensitive to small changes in topography and tidal fluxes (Hughes et al., 1998). The main factors affecting the hydrology of such wetlands are vegetation, rainfall, seasonal variations in evaporation and transpiration, extreme tidal or flood events, and variations in regional groundwater flow (Hughes, 1998). Hydrology is probably the single most important determinant of the establishment and maintenance of wetlands (Mitsch and Gosselink, 1993), and is essential in understanding and quantifying wetland functions and processes (Greeson et al., 1979). Anthropogenic hydrological modifications to rivers and their drainage basins, as well as, upland development have changed the physical, chemical and biological character of river-floodplain systems (Weilhoefer et al., 2008).

Floodplain wetlands are intimately linked to rivers and their watersheds through the pulsing of floodwaters (Weilhoefer et al., 2008), which is thought to be the major driver of biota in these environments (Junk et al., 1989). Floodplains are characterized by hydrological fluctuations, and the alternation of terrestrial and aquatic phases contribute to a high biodiversity (Gopal and Junk, 2000). The degree of tolerance of species to hydrological extremes (floods and drawdown events) determines the structure of macrophyte communities (van Geest et al., 2005a). Flooding events are important in the maintenance of macrophyte richness and succession (van Geest et al., 2005a), while drawdown events determine composition and abundance of aquatic plants (Wilcox and Meeker, 1991). Drawdown events can have catastrophic effects on aquatic vegetation, decreasing the aboveground biomass of most species (Richardson et al., 2002). Moreover, Van Geest et al. (2005a) observed macrophytes dominated by desiccation-tolerant species along shorelines of lakes disturbed by frequent drawdown events.

Analyses of remote sensing time series data show that more than $70 \%$ of swamps in the upper Nile and Congo basins have been lost in less than 20 years (Maclean, 2004), with about $50 \%$ of the papyrus wetlands in the Kenyan part of Lake Victoria being lost over the period 1969 to 2000 (Owino and Ryan, 2007). In common with the trend worldwide (Millennium Ecosystem Assessment, 2005; Mitsch, 2010), many researchers have attributed papyrus wetland losses around Lake Victoria to: (i) increase inhuman population pressures (Balirwa, 1995, van Dam et al., 2007), (ii) conversion to agriculture through drainage (Mafabi,
2000; Owino and Ryan, 2007; Schuyt, 2005), (iii) unsustainable levels of exploitation driven by perennial harvesting (Osumba et al., 2010), (iv) lake level fluctuations (Awange et al., 2008; Kiwango and Wolanski, 2008), and (vi) challenges presented by climate change (Odada et al., 2009). Over-exploitation and destruction of wetland vegetation curtail the filter function of wetlands as pollutants and nutrients are carried directly into the lake when the vegetation of wetland macrophytes is destroyed (Okeyo-Owuor, 1999).

Past studies on Lake Victoria papyrus wetlands (Jones and Muthuri, 1984; van Dam et al., 2007) have focused in detail, on some ecological component of the wetland, while socio-economic studies (Gichuki et al., 2001; Maclean, 2003) are few. Studies on wetland hydrology are quite limited, despite many works on catchment hydrology (Kizza et al., 2009; Mistry and Conway, 2003; Ogallo, 1988; Ongwenyi et al., 1993) in the Lake Victoria region. Because of the intimate relationship between shoreline wetland ecology, socio-economics and hydrology, knowledge of ecohydrology is critical if we want to predict and manage changes in wetland environments. Recent investigations by Kipkemboi (2006) and Kiwango and Wolanski (2008), have highlighted the importance of lake level fluctuations to the wetland's ecological functioning and impact on community livelihoods. Despite the many modifications on the hydrological flow regimes of major rivers flowing to Lake Victoria in the last 60 years, no studies have been undertaken to understand the ecohydrological functioning of the numerous floodplains and delta wetlands associated with such rivers.

Lake Victoria wetland ecosystems have been recognized to provide various functions and services (Gichuki et al., 2001; Kansiime and Nalubega, 1999; Kipkemboi, 2006), which include: groundwater recharge and discharge, flood control, water storage and purifycation, storm protection and windbreak, food chain support, freshwater fisheries, biodiversity, carbon storage and climate regulation. These functions and services provided by the wetlands have benefits for the wetland itself, surrounding ecosystems, and local and regional communities. The Nyando Wetland is one of the largest and economically important wetland ecosystems fringing the Lake Victoria shoreline and performs important hydrological, ecological and socioeconomic functions (Kipkemboi, 2006; van Dam et al., 2011).

In this study, we determined the spatio-temporal changes (1950-2008) and analyzed the main influencing hydrological factors of a papyrus dominated floodplain wetland known as Nyando Wetland that is located on the eastern shores of Lake Victoria, Kenya. The study was carried out as a State of the System (SoS) 


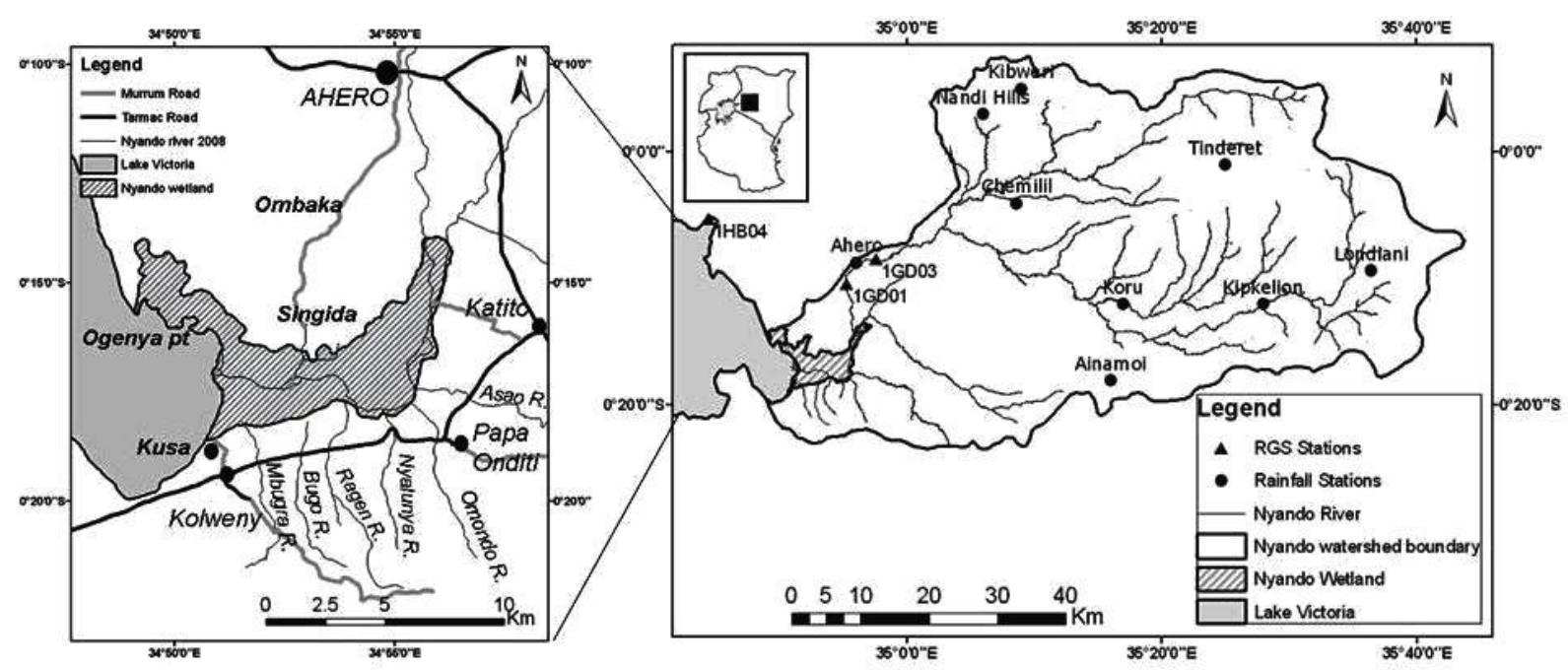

Figure 1. Location map of Nyando Wetland (left panel) and its Nyando Catchment (right panel) and hydrometric network and Nyando.

analysis to: (i) provide a basis for detailed experimental investigations and hydrological modeling, and (ii) integrate with the ecological and socio-economic studies under the ECOLIVE project (van Dam et al., 2011; http://www.unesco-ihe.org/ecolive). The study period was marked by extreme flood and drawdown events that have contributed to the current state of Nyando Wetland.

\section{MATERIALS AND METHODS}

\section{Study area}

This study was carried out in 2009-2010 at a 4,000 ha lowlying swamp, commonly referred to as Nyando Wetland, which is located between a terrestrial and aquatic environment on the eastern shores of Lake Victoria (W inam Gulf), Kisumu County, Kenya (Figure 1) (van Dam et al., 2011). The Nyando Catchment has an area of $3,600 \mathrm{~km}^{2}$ while Lake Victoria, the second largest freshwater lake in the world is $68,800 \mathrm{~km}^{2}$ in area. The extensive Kano floodplains and surrounding Nandi and Kendu Escarpments define the physiography of the wetland, which rises from $1134 \mathrm{~m}$ at the lake shoreline to $1145 \mathrm{~m}$ in the floodplains. Like most wetlands bordering Lake Victoria (Kansiime et al., 2007), Nyando Wetland vegetation is dominated by Cyperus papyrus L. (papyrus) and other less dominant species such as Phragmities mauritianus and Vossia cuspidate.

The most important sources of water supply to the wetland are the Nyando River, Lake Victoria and local rainfall. In general, the wetland experiences a bimodal rainfall pattern, with long rains occurring in March-May and short rains in OctoberDecember. The seasonal variability of mean temperature in Nyando Catchment is bimodal, with two peaks in March and October. Temperature ranges from 13 to $31^{\circ} \mathrm{C}$ in the wetland and 8 to $24^{\circ} \mathrm{C}$ in the highlands. Mean monthly temperatures are higher in the lowlands at $21^{\circ} \mathrm{C}$ and lower in the highlands at $16^{\circ} \mathrm{C}$.

\section{Geology and hydrogeological setting}

The geology of the Nyando Wetland is characterized by the
Pre-Cambrian system (grano-diorites), Tertiary and Quaternary volcanics (granites, rhyolites and phonolites) and Alluviums (Saggerson, 1947) (Figure 2). The metamorphic formations are the oldest rocks in the area dating back to Pre-Cambrian times (Shackleton, 1952). During Tertiary-Quaternary times, the region experienced the occurrence of several episodes of volcanic activity that were accompanied by widespread regional rifting and faulting.

The consolidated sediments were formed due to deformation and fracturing of the Kavirondo Rift Zone in Miocene-Pliocene times. In recent times, the unconsolidated sediments (sand, silt and clay) were deposited in Lake Victoria, and became interbedded over the Kano floodplains area with alluvium and colluvium brought down from the surrounding highlands (Millman, 1973). The last geological event is the migration of the Nyando River channel that has re-defined the geomorphology of Nyando W etland environment.

The hydrogeological setting of the Nyando Wetland is defined by two separate groundwater systems (DHV Consulting Engineers, 1988). A deep groundwater system occurs in the Lower Pleistocene deposits, while a shallow groundwater system is found in the unconsolidated sediments. The two systems are separated by an aquiclude, which comprises mainly of clayey materials, for example, mudstone and siltstone (Figure 2). The shallow aquifers vary considerably in thickness $(0$ to $15 \mathrm{~m})$ and are usually subject to seasonal fluctuations as compared to the thick (50 to $250 \mathrm{~m}$ ) deep aquifers that store large volumes of groundwater. It is generally assumed that the shallow aquifers are recharged by rainwater percolation and the river system, and that the deep aquifers are recharged by shallow unconfined aquifers, shear zones and influent streams flowing from the escarpments. However, a more detailed understanding of the processes and their variability in space and time is subject to detailed and ongoing experimental and modeling investigations by the authors of this paper.

\section{Soils}

The Kano floodplains are characterized by a complex succession in the soil profiles. The plains are dominated by deep accumulations of colluvium that have been resorted by local flash 

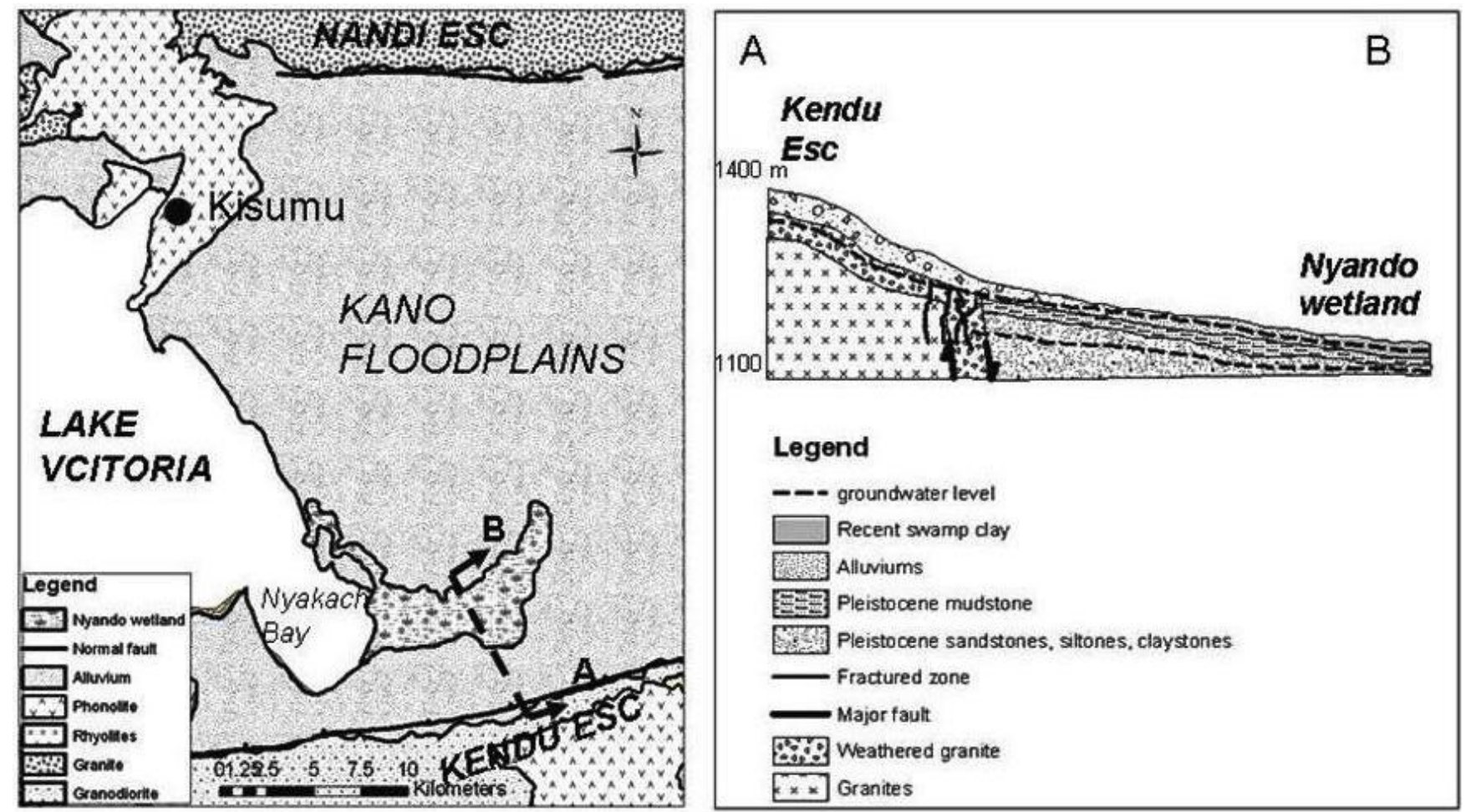

Figure 2. Geological map of Nyando Wetland (left panel) and hydrogeological cross-section (right panel) (source: Saggerson, 1950; DHV Consulting Engineers, 1988).

floods and become mixed with lenses of alluvium. Dark coloured clays and clay loam are the most widespread of the alluvial soil types; their colour vary from brown to black, which corresponds to a variation in clay content in the subsoil (Millman, 1973). When moistened, these soils become plastic, slightly sticky and loose any semblance of a structure, and crack on drying to form a weak, angular, blocky structure. These soils are usually termed 'black cotton soils' and represent considerable problems for agricultural development (Millman, 1973). The most common soil types include luvisols, greysols and fluvisols (W aruru et al., 2003).

\section{Datasets and data properties}

In this study, daily rainfall, discharge and lake level data collected at key monitoring stations in the Nyando catchment (Figure 1) for the period 1950-2009, were obtained from the Kenya Meteorological Department and the Water Resources Management Authority. The chronogram shown in Figure 3 shows a rise in data availability in 1970-1990 attributed to the WMO Hydromet Project (WMO, 1982). As observed by other researchers (Kizza et al., 2009), the expansion in the hydrometric network was regional, covering the Upper Nile, but declined in the 1990s when the project came to an end. In practice, the operational and maintenance costs of hydrometric networks are a big challenge, especially in the developing countries. This calls for further collaborative engagements between local and international players.

More than $50 \%$ of the stations had missing data ranging from a few days to several years. The data gaps were filled using linear regression and interpolation techniques. The most notable constraint for rainfall stations was that there was so much variability between nearby stations. Therefore, rainfall stations with only complete annual data series and having data for at least 30 years were used in the analysis. Double mass curves were used to test for the consistency of annual rainfall data. The river gauging stations were correlated with upstream stations to generate a long term time series. The lake levels had missing data for only two years, which was considered not to generally influence the long-term data series. Another constraint was limited recent rainfall data.

\section{Statistical methods}

Several statistical tests can be used to detect trends and homogeneity in time series hydrological data. These methods are broadly classified as parametric and non-parametric. Nonparametric (distribution free) tests are so called because the assumptions underlying their use are 'fewer and weaker' than those associated with parametric tests (Siegel and Castellan, 1988). For this reason, nonparametric methods are commonly used in hydrological investigations, especially when the data is considered skewed. However, parametric tests are much more flexible, and allow for testing a greater range of hypotheses. In this study, we used parametric and non- parametric methods.

We first applied the non-parametric Spearman's rank correlation method to evaluate the absence of linear trends in the data. Change-point analysis was then performed using both the nonparametric Pettitt (1979) test and the parametric Standard Normal Homogeneity (SNHT) test (Alexandersson, 1986; Alexandersson and Moberg, 1997). On identification of change-points in the data series, split-record tests on means (t-test) and variances (F-test) were carried out to quantify the magnitude of the changes and to test the significance of the differences in the subsets before and after the change point. All the statistical tests were carried out 


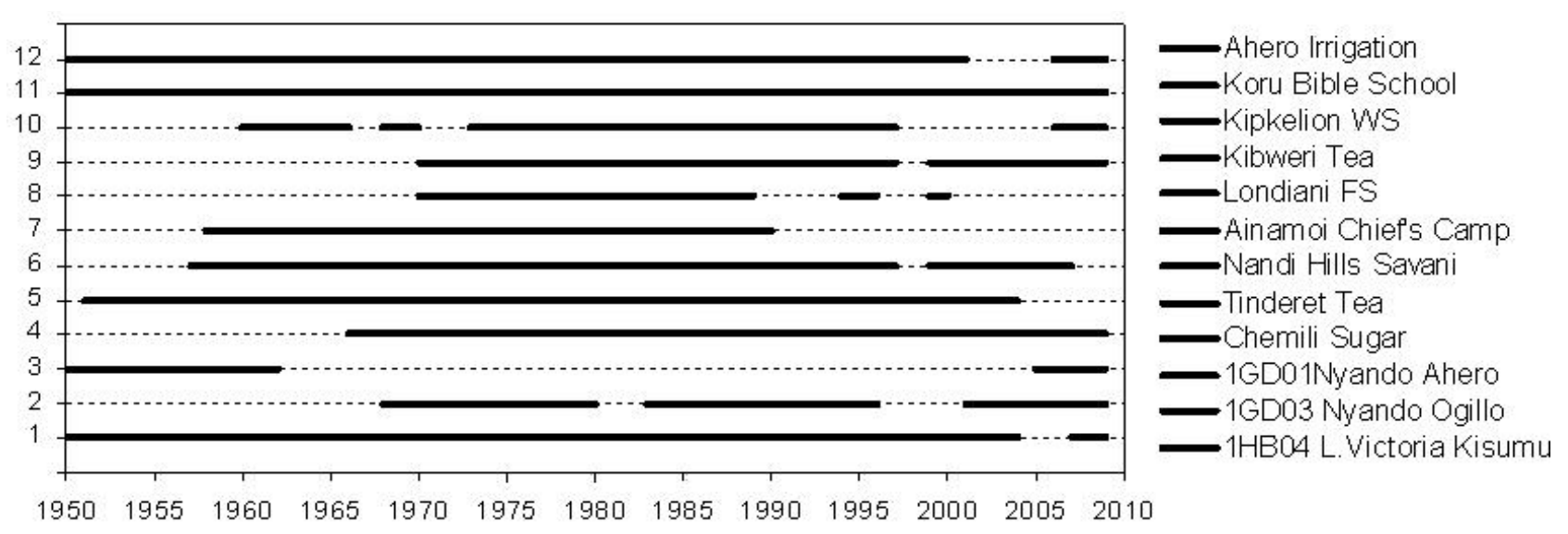

Figure 3. Chronograms showing years with complete total monthly rainfall data series.

Table 1. Spatial data used for characterization of Nyando wetland in this study.

\begin{tabular}{lcccl}
\hline Data type & Date & Scale/resolution & Sheet no./scene & Source \\
\hline Geological map & $01 / 07 / 1950$ & $1: 125,000$ & 41 & Mines and Geology, Kenya \\
Topographic maps & $31 / 07 / 1967$ & $1: 50,000$ & $116 / 2,116 / 4$ & Survey of Kenya \\
Landsat 2 MSS & $01 / 02 / 1973$ & $30 \mathrm{~m}$ & $182 / 60$ & USGS \\
Landsat 4 TM & $08 / 03 / 1986$ & $30 \mathrm{~m}$ & $170 / 60$ & USGS \\
Landsat 7 ETM+ & $05 / 02 / 2001$ & $30 \mathrm{~m}$ & $170 / 60$ & USGS \\
Landsat 5 ETM+ & $28 / 09 / 2008$ & $30 \mathrm{~m}$ & $170 / 60$ & USGS \\
\hline
\end{tabular}

using the SPELL Stat package (Ashagrie et al., 2006). Critical values for the Spearman's rank correlation was less than or equal to $2.002 \mathrm{t}$-student distribution function at $\mathrm{n}-2$ degrees of freedom at $5 \%$ significance level. The Pettit test had a critical level of $80 \%$ probability for significance of change points, while the SNHT test had 8.65 at $90 \%$ significance level. The year corresponding to the highest probability was considered the end of the first subset and the year following it as the first year of the next subset.

\section{Image analysis}

The methodology used for image analysis was a combination of optical image analysis and field survey as suggested by MacAlister and Mahaxay (2009). Spatial data were registered to the UTM World WGS84 coordinate system, zone 36 (south), using Arc GIS 9.3 program (Table 1). First, satellite images were preprocessed in the ERDAS Imagine 9.2 digital image processing program. Analyses of satellite data was limited to only single season (dry) imagery due to the lack of suitable (cloud free) wet season scenes. The dry season images were $c$ onsidered useful in assessing time series spatio-temporal changes in the wetland. We selected proven band combinations of the Landsat MSS (bands 2, 3, 4), Landsat TM (bands 2, 3, 4 and 5) and Landsat ETM+ (bands 3, 4, 5 and 7) images for wetland studies (Melack et al., 1994; Walsh et al., 1990). The images were ortho-rectified and layer stacked to generate false colour composites for wetland delineation using ERDAS Imagine 9.2 digital image processing system. Single panchromatic thermal bands (band 5) were selected for delineation of surface water bodies (river channel).

The pre-processed satellite images and geological map were registered to the 1:50, 000 topographic maps in Arc GIS 9.3.1, by utilizing the tie points (ground control points) technique but with an affine transformation. Eight ground control points (GCPs) were identified and selected in the four corners, at the east-west and north-south centers of the images. The maximum root mean square (RMSE) of rectification was $<30 \mathrm{~m}$. A standard histogram equalization image enhancement technique was applied for a better visibility of water-wetland-dry land boundaries (Perez et al., 2001). The swamp area (papyrus dominated wetland) and the main river course were visually interpreted on the satellite images and geological map, before on-screen digitization to generate polygon and polyline maps. From these maps, a number of numerical parameters (for example, total wetland area, perimeter length, lateral distance of river displacement) were calculated in order to evaluate the change in wetland size and river channel migration during the period 1950 2008.

Field survey was conducted in the Nyando Wetland and its surrounding areas in the period September 2009 to May 2010. The most common approach was to: (i) mark waypoints with Global Positioning System (GPS) along the main Nyando River channel and at boundaries of typical wetland habitats (ii) verify existing geological, topographic, soil, and land use and land cover maps of the wetland and its surrounding area. Georeferencing of Nyando River channel was conducted aboard a canoe (local boat).

Field work was carried out along two main transects: lateral to the lake and across the river, taking into consideration the hydrological, ecological and socio-economic gradients. All georeferenced data were plotted in Arc GIS. For accuracy assessment, field sample points (way points) were overlaid on the Landsat ETM+ 2008 imagery. Each waypoint was then reviewed 
Table 2. Properties of total annual rainfall data series for Nyando Catchment.

\begin{tabular}{|c|c|c|c|c|c|c|c|c|c|c|}
\hline Station name & $\begin{array}{c}\text { WMO } \\
\text { number }\end{array}$ & $\begin{array}{l}\text { Annual mean } \\
\text { (mm/year) }\end{array}$ & CV & $\begin{array}{c}\text { SD } \\
\text { (mm/year) }\end{array}$ & Skewness & Kurtosis & $\begin{array}{c}\text { Max } \\
\text { (mm/year) }\end{array}$ & $\begin{array}{c}\text { Min } \\
\text { (mm/year) }\end{array}$ & $\begin{array}{l}\text { Start } \\
\text { year }\end{array}$ & $\begin{array}{l}\text { No. of } \\
\text { years }\end{array}$ \\
\hline Ahero Irrigation & 9034086 & 1148 & 0.16 & 185 & -0.35 & 2.24 & 1612 & 547 & 1950 & 56 \\
\hline Koru Bible School & 9035148 & 1642 & 0.19 & 318 & 0.10 & 0.08 & 2499 & 680 & 1950 & 60 \\
\hline Kipkelion WS & 9035258 & 1273 & 0.25 & 316 & 0.74 & 1.50 & 2238 & 650 & 1960 & 40 \\
\hline Kibweri Tea & 8935161 & 1233 & 0.22 & 267 & 0.89 & 2.37 & 2150 & 684 & 1970 & 39 \\
\hline Londiani FS & 9035002 & 1117 & 0.18 & 202 & 0.01 & 0.39 & 1499 & 677 & 1970 & 39 \\
\hline Ainamoi C. Camp & 9035199 & 1605 & 0.26 & 418 & -0.21 & 0.54 & 2708 & 748 & 1958 & 36 \\
\hline Nandi H. Savani & 8935033 & 1587 & 0.21 & 338 & -0.6 & 0.11 & 2124 & 739 & 1957 & 51 \\
\hline Tinderet Tea & 9035263 & 1735 & 0.18 & 318 & 0.01 & 0.30 & 2401 & 926 & 1950 & 55 \\
\hline Chemilil Sugar & 9035274 & 1452 & 0.14 & 200 & -0.09 & -0.75 & 1835 & 1106 & 1966 & 44 \\
\hline
\end{tabular}

reviewed by comparing it with the corresponding river channel and wetland boundaries delineated on the image.

\section{RESULTS AND DISCUSSION}

\section{Statistics}

A summary of descriptive statistics for rainfall data series used in this study is presented in Table 2. The highest mean annual rainfall of 1735 $\mathrm{mm}$ /year was observed at Tinderet Tea station, with Londiani Forest station recording the lowest value of $1117 \mathrm{~mm} /$ year. In general, the highland stations (Tinderet Tea, Ainamoi Chief's Camp, Nandi Hills Savani, Koru Bible) receive more rainfall than stations in the plateau (Kipkelion Water Supply and Londiani Forest) and lowlands (Ahero Irrigation and Chemilil Sugar). Though located in the highlands close to Nandi Hills Savani, Kibwari Tea station has a mean annual rainfall of only $1233 \mathrm{~mm} / \mathrm{year}$. The location of the plateau stations on the leeward side of the surrounding highlands (Tinderet, North Tinderet, Mt Londiani and SW Mau Forest Complex) shields them from the south-easterly monsoon winds that bring about orographic rainfall. The lowland stations which are characterized by the Kano floodplains and Lake Victoria shoreline receive pre-dominantly convectional rainfall. The standard deviation varies from $185 \mathrm{~mm} /$ year at Ahero to $418 \mathrm{~mm} / \mathrm{y}$ at Ainamoi. The coefficient of variation (CV) ranges from $14 \%$ at Chemilil Sugar to $26 \%$ at Ainamoi Chief's Camp, confirming that rainfall varies considerably at each station from year to year. This observation compares with the average 19\% computed by Kizza et al (2009) for rainfall stations in Lake Victoria basin.

Statistical tests show that time series data from Ainamoi Chief 's Camp, Chemilil Sugar, Kibwar Tea Estate Nandi Hills, Kipkelion Water Supply, Londiani Forest Station, Tinderet Tea Station and Nandi Hills Savani rainfall stations, Nyando River RGS stations (1GD01 and 1GD03) and the lake level station at Kisumu bay (1HB04) are homogenous, since the null hypothesis for Spearman's rank correlation for absence of linear trend, was not rejected at 5\% level of significance. Although the null hypothesis was rejected for Koru
Bible School and Ahero Irrigation Research Stations, the data were still considered useful since lack of independence in the datasets was related to change of station locations.

\section{Rainfall variability}

The Pettit change point analysis indicates a shift in total annual rainfall in Nyando catchment in 1979, with a probability of $95 \%$. The F-test and t-test parametric tests reveal a stable variance, and the presence of a significant downward jump in the mean from 1520 to 1403 $\mathrm{mm}$ /year as compared to the long-term mean of $1462 \mathrm{~mm} /$ year (Figure 5). These results are consistent with rainfall trends at Ainamoi Chief's Camp, Koru Bible School, Nandi Hills Savani and Tinderet Tea stations, but contrast with observations at Ahero and Kipkelion stations which show significant upward trends. The Chemilil Sugar, Kibwari Tea Estate and Londiani Forest stations did not show any significant trends. The decline in catchment rainfall is consistent with findings by Awange et al. (2008) for 


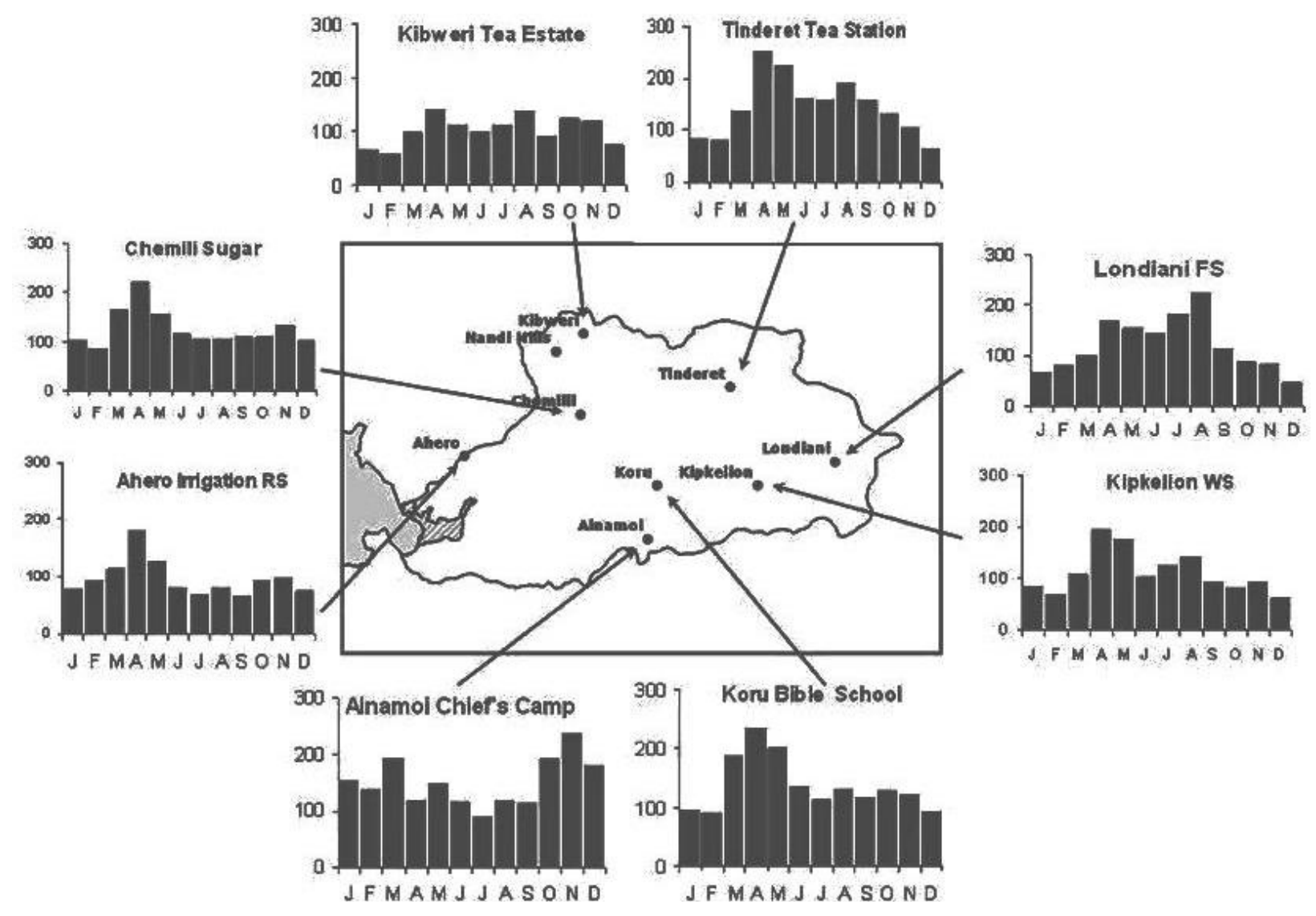

Figure 4. Long-term mean monthly rainfall variability at key selected stations in Nyando River basin.

the Lake Victoria basin. On a longer time scale, Kiiza et al. (2009), has shown that the Lake Victoria basin experienced a predominantly positive trend over the twentieth century with 1960s representing a significant upward jump in the basin rainfall. Mistry and Conway (2003) reported that rainfall in the Lake Victoria basin does not exhibit any marked trends across the twentieth century, although rainfall totals reveal an irregular harmonic pattern of quasi-periodic fluctuations on seasonal and annual time scales.

A visual inspection of the long-term mean monthly rainfall distribution from eight selected stations in the study area (Figure 4) shows a bimodal seasonal pattern of rainfall variability. The long rains occur in March-May (MAM) months at all stations. However, the occurrence of short rains varies between stations. In general, the lowland stations and some highlands stations receive short rains in the October-December (OND) months, while a few highland stations experience short rains in the July-September (JAS) months.

The Pettit and SNHT tests show a significant downward trend in the seasonal long rains (MarchMay) and no significant trends in the seasonal short rains (October-December) (Figure 5). Kizza et al. (2009) showed that, short rains tend to have more trends than the long rains in the Lake Victoria basin. The long rains season contribute $34 \%$, while the short rains season account for $22 \%$ of the $1462 \mathrm{~mm} /$ year mean annual rainfall. The rains falling in July-September are higher than the short rainy season and contribute more than $24 \%$ of the annual total. In general, more than half $(54 \%)$ of mean annual rainfall is received in the January-June months. Seasonal variations in rainfall respond to the north-south movement of intertropical convergence zone (ITCZ) (Millman, 1973; Mistry and Conway, 2003; Ogallo, 1988), and enhanced by a strong nocturnal land breeze from Lake Victoria (Flohn and Fraedrich, 1966) and westerly winds from the Congo basin.

A plot of mean annual rainfall anomalies (Figure 6), following the method suggested by Awange et al. (2007b) to define meteorological drought was used to determine the Drought Severity Index (DSI) (1st quartile) and the wet (3rd quartile) thresholds. Results show that the wet years in the Nyando River basin were observed in 1951, 1961-1964, 1968, 1972, 1977-1978, 19961998, 2002 and 2006. The episodic rainfall events of 1961-1964 ('Uhuru' rains) and 1996-1998 that exacerbated flooding problems in the entire Lake Victoria basin were reported by many authors (Awange et al. 

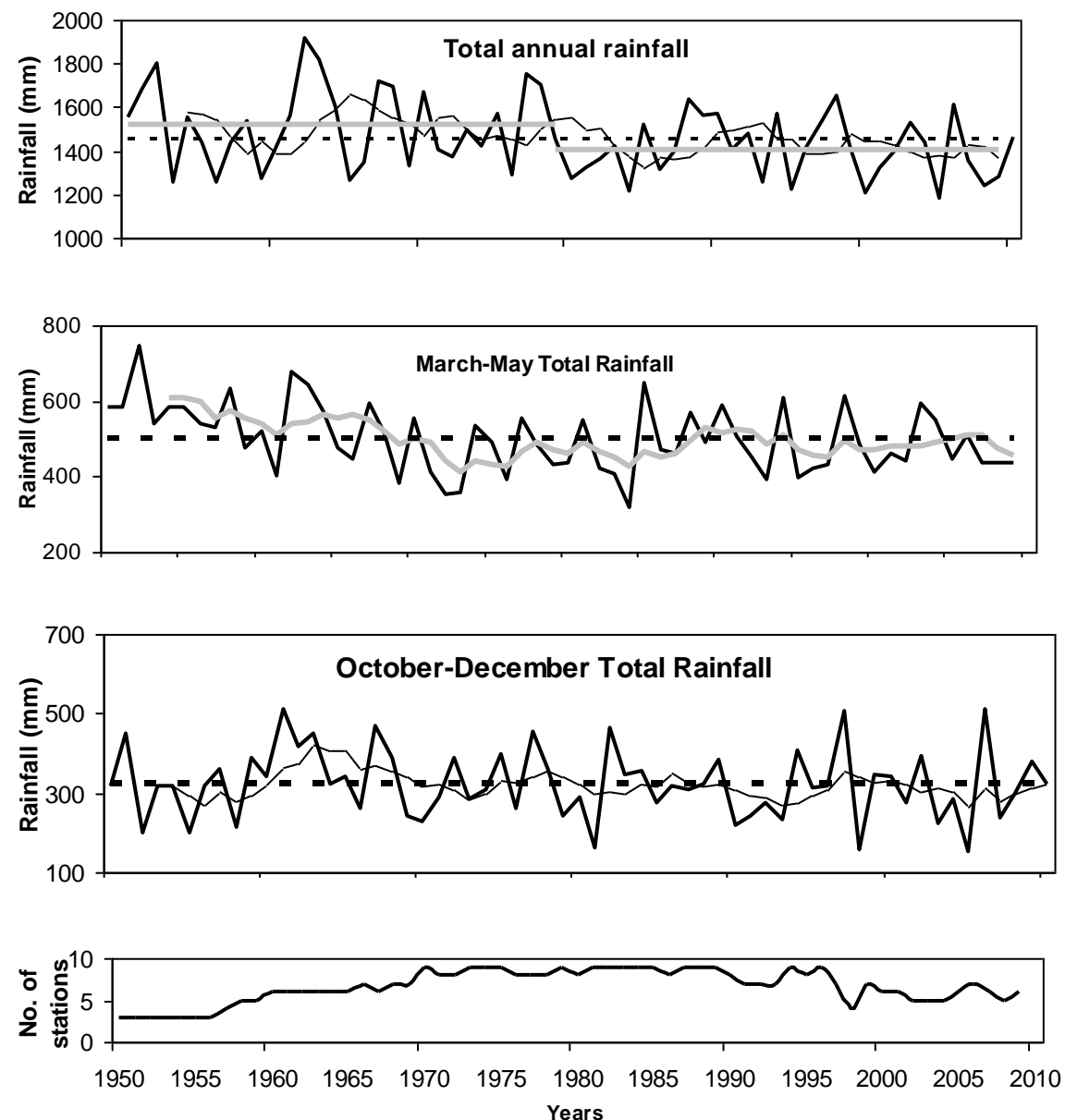

Figure 5. Total rainfall (annual, March-May and October-November) (dark thick line) for study stations with an average (dotted line), 5-year moving average (dark thin line) superimposed and change-point results (thick-grey line). The lower panel shows the number of stations used to compute the means.

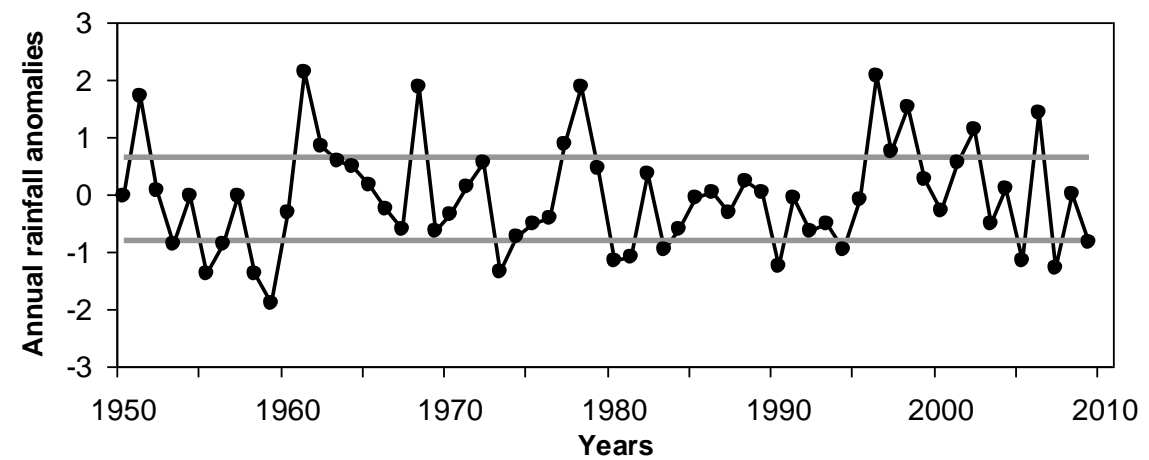

Figure 6. Time series of annual rainfall anomalies defining the wet, normal and drought years, determined by the drought severity index (DSI) and wet thresholds (horizontal lines).

2008; Kizza et al., 2009; Millman, 1973; Mistry and Conway, 2003; Ongwenyi et al., 1993). The drought years were observed in 1954, 1955-1956, 1958-1959,
1973, 1980-1981, 1984, 1990, 1994, 2005, 2007 and 2009, with the 1955-1956 period being the most devastating. The episodic flood and drought events have 

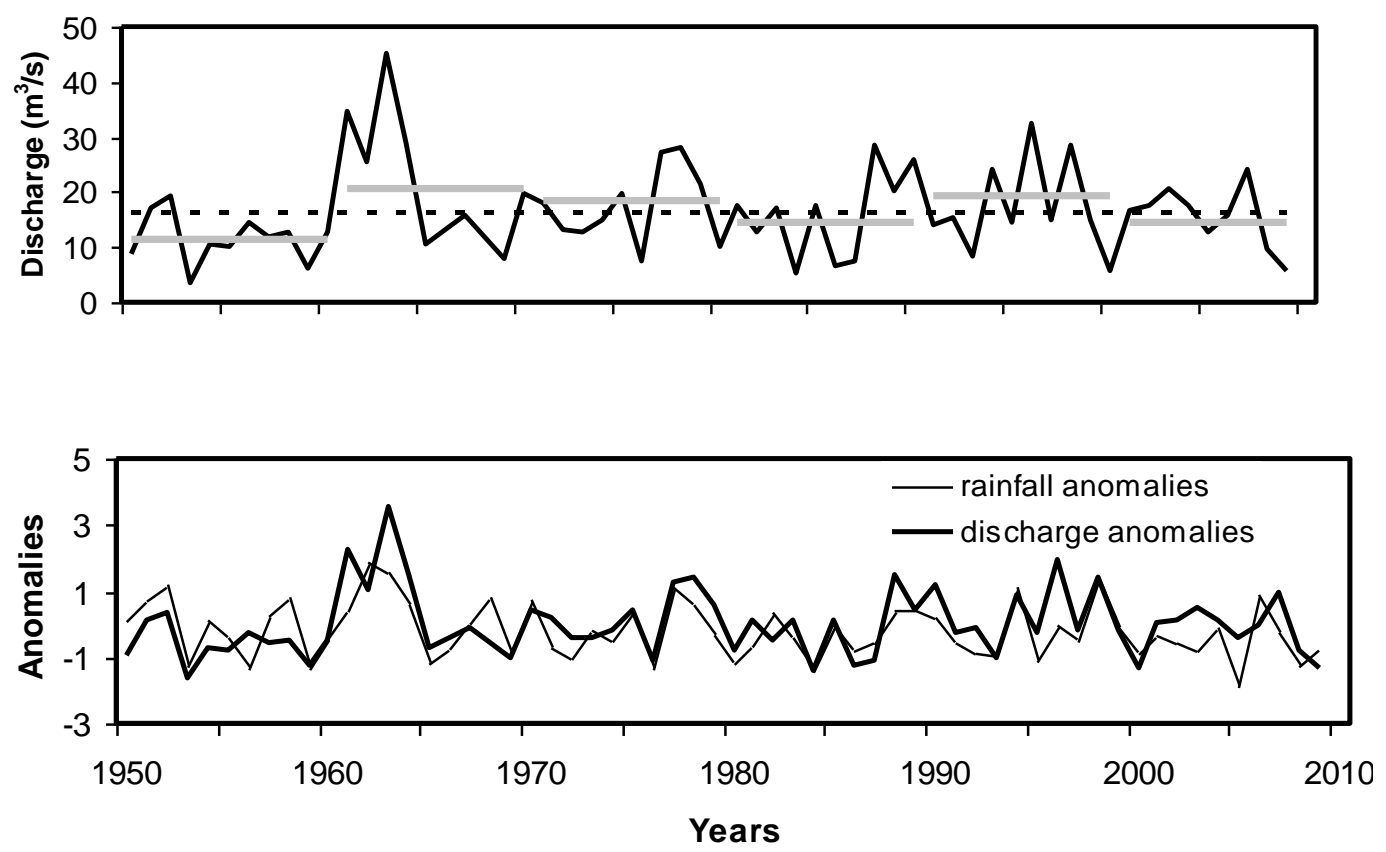

Figure 7. Mean annual discharges (top panel) (dark line) for Nyando River recorded at station 1 GD03 showing changes in decadal means (grey horizontal lines) as compared to the 60-year long-term mean (dashed line) and comparison of total annual rainfall and mean annual discharge anomalies.

been linked to the EI Niño Southern Oscillation (ENSO), Indian Ocean Dipole (IOD) and many other large-scale climate systems prevalent in the East African region (Ogallo, 1988; Mistry and Conway, 2003). Prominent rainfall cycles over Lake Victoria basin are 2 to 2.5 years, 2.7 to 3.3 years with less prominent cycles at 3.5 to 4.4 , 5,6 to $6.5,7$ to 8 and 10 to 11 years (Ogallo, 1993).

\section{River flow variability}

Statistical change-point analyses of river flow records show a shift in 1960 of mean annual discharge for Nyando River (Figure 7) with a stable variance. The decadal mean discharge increased by $80 \%$ in the 1961 to 1970 subset from the initial value of 11.45 $\mathrm{m}^{3} / \mathrm{s}$ observed in the 1951-1960 subset. The river flows reduced by 11.4 and $21.9 \%$ in the next two decades, before rising by $35.0 \%$ in 1990 s and dropping by $24.0 \%$ in the last decade. The decadal mean discharges were higher than the 60 -year long-term mean of $16.4 \mathrm{~m}^{3} / \mathrm{s}$ from 1960 to 1980 and 1990 to 2000, but remained lower in 1950s, 1980s and the last decade. The flow regime of Nyando River is characterized by high and low flows. The peak flows (based on maximum annual method) show an increasing trend with a change-point in 1987. The seven-day annual minimum discharge records indicate significant increases during and after prominent rainfall events of 1961-1964 and 1996-1998.
There is a positive correlation of 0.64 between mean annual river discharge and catchment mean annual rainfall (Figure 7). The upward shift in Nyando river discharge in the 1960s and 1990s coincided with El Nino events of 1961-64 and 1996-1998. The continued decline in catchment annual rainfall after 1979 , may explain why the river has also exhibited declining trends, enhanced by an increase in water demand especially for irrigated agriculture. The highest mean annual discharge of 45.3 $\mathrm{m}^{3} / \mathrm{s}$ was recorded in 1963 during the El Niño rains of 1961 to 1964. Fohn (1987) observed that the prominent rainfall event caused drastic rises in the White Nile discharges and widespread flooding. At seasonal scale, the river exhibits a tri-modal flow pattern with a primary peak occurring in May and secondary peaks in August and November in response to the seasonal rainfall pattern (Figure 8).

The mean monthly rainfall for the catchment has the highest value in April, August and November. The hydrograph of the river peaks after a one month time lag after the onset of the long rains, but peaks during the same months in the subsequent short rains periods. The long rains are usually preceded by the long dry spell, hence allowing the catchment to absorb the first rains before the river peaks. The high elevation areas of the catchment are generally wet on the onset of the short rains. Generally, discharges observed in the MAM, JAS and OND months contribute 30, $3020 \%$ of total annual discharge, respectively. The mean monthly discharge is evenly distributed with $49 \%$ 


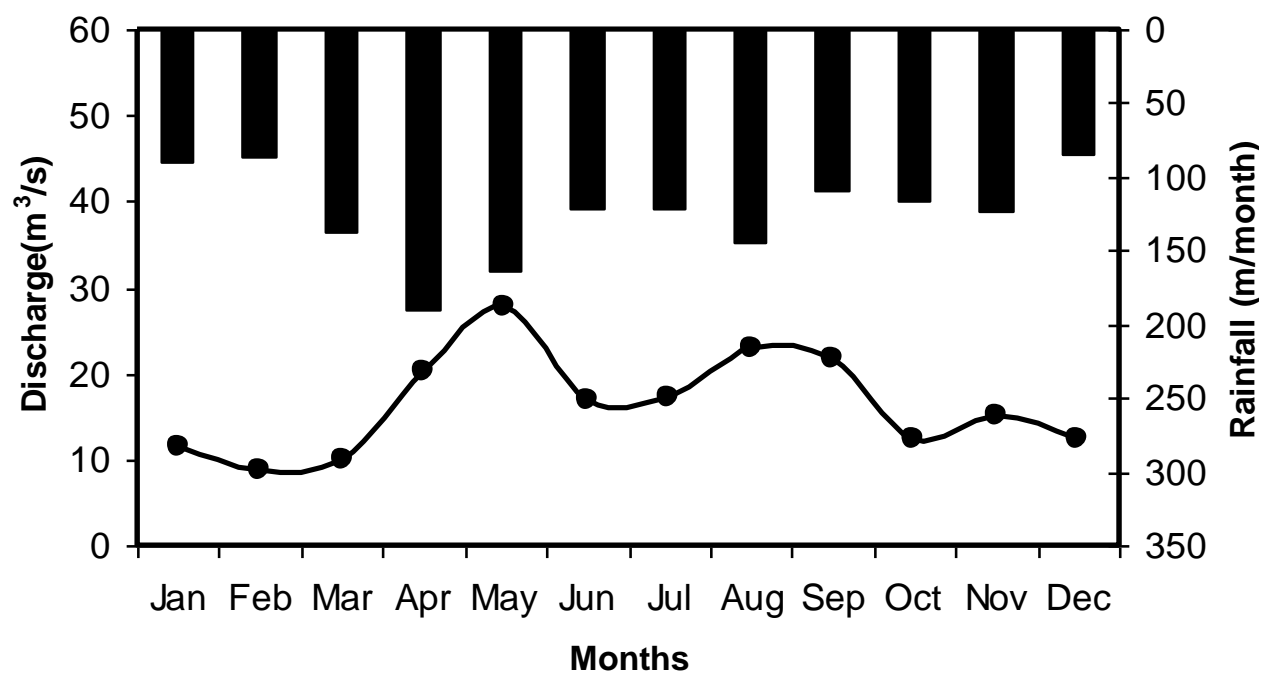

Figure 8. Comparisons of total mean monthly hyetograph (mean of 10 stations) and Nyando River hydrograph at station $1 \mathrm{GD} 03$.

occurring in the January-June months.

Flood frequency analysis using the Gumbel EV1 distribution function has indicated that a flood of 1.1 years return period is $41.79 \mathrm{~m}^{3} / \mathrm{s}$ at $1 \%$ probability of non-exceedance. This may explain why Nyando River inundates the floodplain perennially, with a commencement-to-flow threshold of about $17-30 \mathrm{~m}^{3} / \mathrm{s}$ along its reaches. The key factors that may be influencing the occurrence of floods in the wetland are climate variability and land use changes in the catchment.

As our results have shown, the relative large frequency and magnitude of floods in the basin may be explained by climate variability. The most prominent flood events have been observed during the OND short rains, which are influenced by the ENSO phenomena. This observation is consistent with findings by other researchers (Ashagrie et al., 2006) who suggested that the recent occurrence of frequent floods worldwide is likely due to climate variability where an increase in heavy precipitation might lead to an overproportional increase in runoff due to non-linear processes. There are evidences that changes in land use have influenced the hydrological regime of various river basins (Tu et al., 2004, Ashagrie et al., 2006). It is, however, more challenging to quantify the impact of land use change on the rainfall-runoff relations for large basins where the interactions between land use, climatic characteristics and the underlying hydrological processes are often more complex and dynamic (Uhlenbrook, 2007, 2009).

\section{Lake level fluctuations}

The SNHT single test shows that Lake Victoria annual mean levels had a shift in 1961 (Figure 9). The F-test and t-test tests show significant upward jumps. The decadal mean annual lake levels jumped from 1134.0 to $1135.43 \mathrm{~m}$ in the 1951-1961 and 1962-1972 subsets, respectively. The level showed an insignificant downward trend in the next two decades before rising slightly in the 1995-2005 subset.

Consequently, the level remained above the long-term mean of $1135.0 \mathrm{~m}$ for 43 years since 1962, before dropping drastically by $1.4 \mathrm{~m}$ to an average of $1134 \mathrm{~m}$ in 2005-2009. The monthly lake levels fluctuations at Kisumu and Entebbe have similar trends with the Nile outflow in the period 1950-1999 (Figure 10). However, the Nile outflow increased steadily from $995.84 \mathrm{~m}^{3} / \mathrm{s}$ to $1354.69 \mathrm{~m}^{3} / \mathrm{s}$ in November 1999 to December 2004, as lake levels in Kisumu and Entebbe declined during the same period. It is most probable that this trend persisted up to 2009 as the lake level fluctuations in Kisumu bay have shown.

The highest recorded lake level at Kisumu station was $1136.2 \mathrm{~m}$ in 1964 after rising by $2.5 \mathrm{~m}$ from 1961 . Similar observations were made by several authors (Millman, 1973; Kite, 1981; Nicholson, 1998; Awange et al., 2008; Conway, 2002; Flohn, 1987; Conway and Hulme, 1993; Birkett et al., 1999) who found that the lake level remained fairly stable throughout the first half of the twentieth century before rising abruptly in 1961 and continued until 1964, when the lake's level approached the high stands of the last century. According to Nicholson (1998), Lake Victoria was characterized by very low levels in the first half of the nineteenth century and a sharp rise of 4 to $5 \mathrm{~m}$ to remain high in the last decades of that century. The prolonged elevation of lake levels are attributed to the initial OND short rains in 1961 and 1997 followed by heavy seasons (Conway, 2002). 

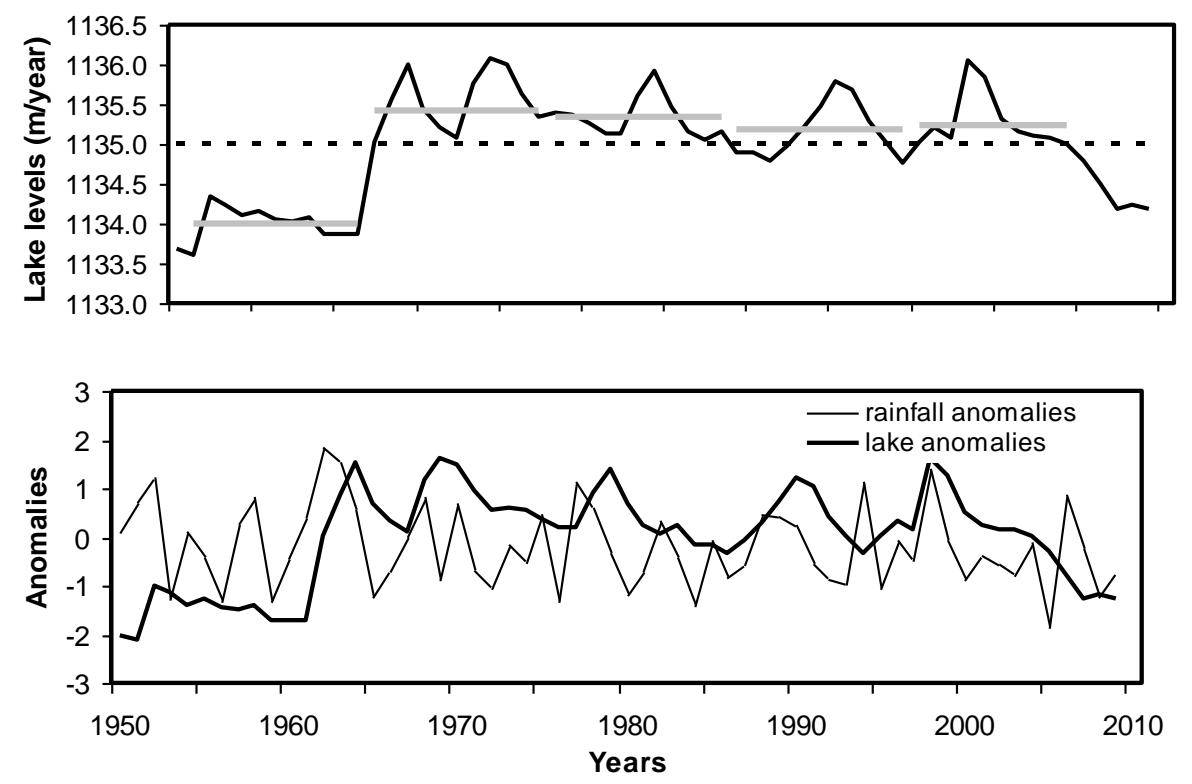

Figure 9. Comparison of mean annual lake level variability (thick dark line) with 60year long-term mean (dotted line) and decadal means (grey horizontal lines) (top panel) and total annual rainfall and lake level anomalies (bottom panel).

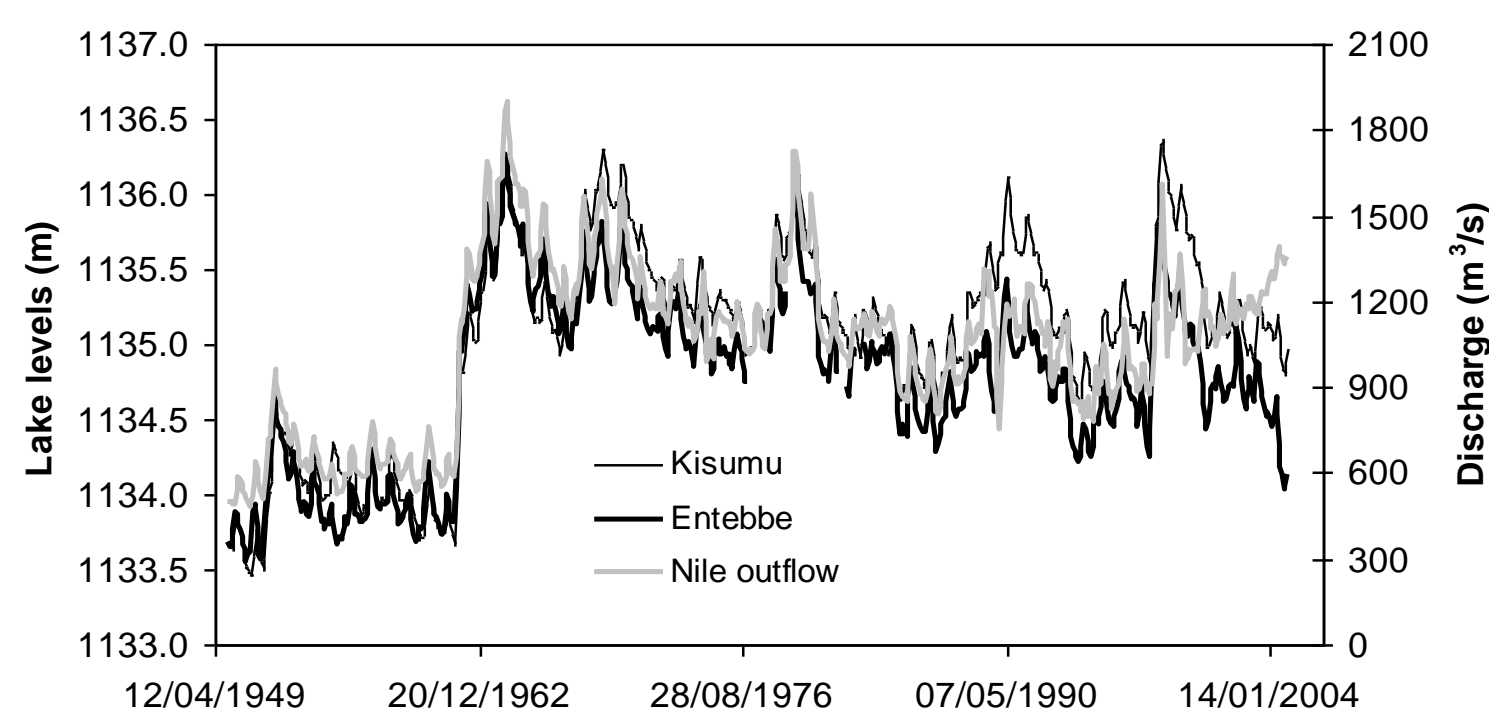

Figure 10. Long-term monthly lake level fluctuations at Kisumu and Entebbe stations and River Nile outflow discharge in the period 1950-2004.

The seasonal lake level pattern is bi-modal, with a primary peak in June $(1135.14 \mathrm{~m})$ and secondary peak in December (1134.94 m) (Figure 11). The monthly mean lake level is lowest in October and February at $1134.9 \mathrm{~m}$. Difference between highest and lowest is $0.244 \mathrm{~m}$. The lake levels respond to regional distribution of rainfall in the Lake Victoria basin, most of which occur in the MAM and OND months. The correlation coefficient of the total annual and seasonal rainfall in Nyando Catchment and the mean annual and seasonal lake level is 0.1 and 0.2 , respectively. The main factor influencing lake level fluctuations can be explained by direct rainfall on the lake surface.

Mistry and Conway (2003) found a strong correlation between the lake rainfall series and the lake levels, with a time lag of 1 to 2 years. Flohn and Fraedrich (1966) estimated lake rainfall to be 25 to $3 \%$ higher than catchment rainfall using a combination of a convection model and rainfall observations around the lake and island stations. Similar differences between lake and 


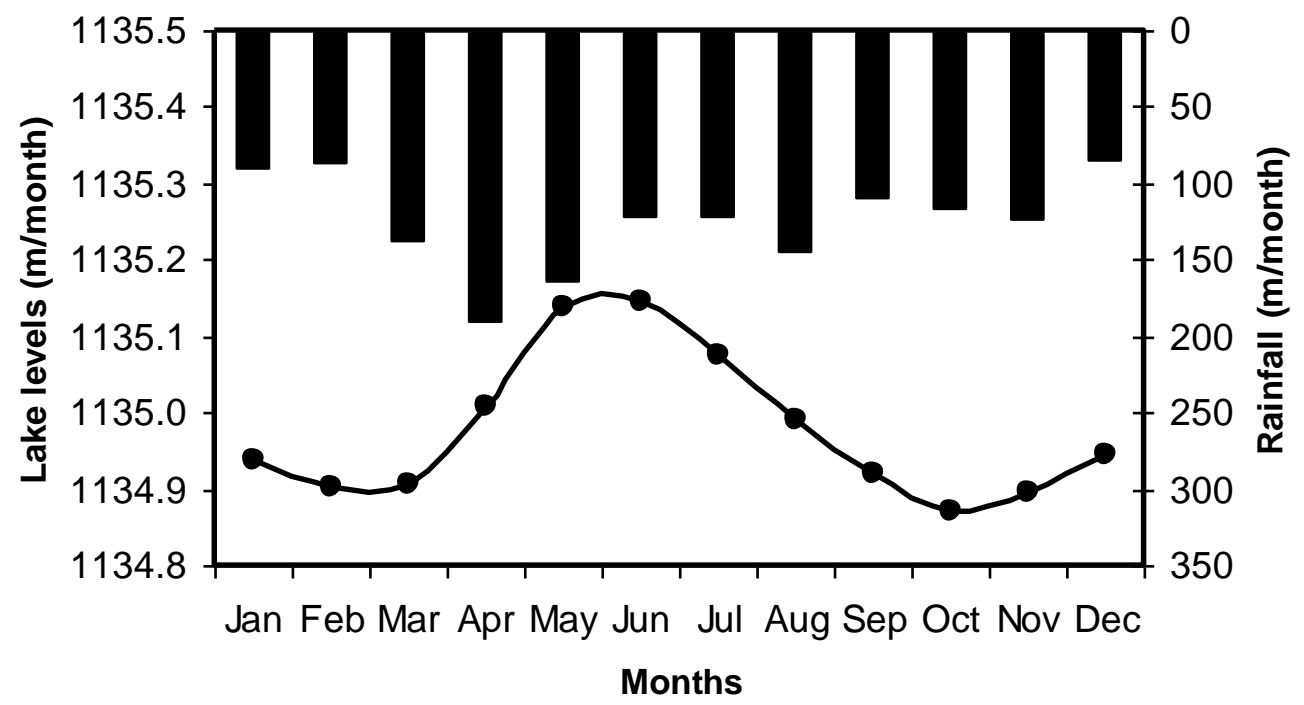

Figure 11. Comparison of Nyando catchment mean monthly rainfall and mean monthly lake levels from 1950-2009.

catchment rainfall were estimated by $\mathrm{Ba}$ and Nicholson (1998), using satellite data. Using their results, Yin and Nicholson (2002) determined that the water balance of the lake is dominated by rainfall over the lake (approximately $1791 \mathrm{~mm} /$ year) and evaporation (1532 mm/year). Tributary inflow and discharge averages are $338 \mathrm{~mm} / \mathrm{y}$ and $524 \mathrm{~mm} / \mathrm{y}$, respectively. Lake rainfall is $82 \%$ of the total inflow; the remaining $18 \%$ is contributed by river inflow. River Kagera alone contributes $32 \%$ of the river inflow (COWI, 2002). Of the outflow, $76 \%$ is due to evaporation from the lake and the remaining $24 \%\left(745.2 \mathrm{~m}^{3} / \mathrm{s}\right)$ is the outflow forming the White Nile River at Jinja (Scheren et al., 2000; COWI, 2002). Using the lake rainfall results of Yin and Nicholson (2002), this study has shown that lake rainfall is $23 \%$ higher than Nyando Catchment rainfall, which is comparable to findings by Flohn and Fraedrich (1966).

It is unlikely that the recent prominent decline in lake levels (Figure 9) can be explained by a decline in rainfall trends alone. Neither can it be wholly attributed to the prolonged long-term and short-term droughts and decrease in river flows to the lake as previously reported by Awange et al. (2008). The increase in the Nile outflow is perhaps the single most important phenomena that has impacted on the lake level fluctuations since 2000 (Figure 10). This finding is consistent with that of several authors (USDA, 2005; Kull, 2006; EAC, 2006; Kiwango and Wolanski, 2008) who attributed the recent episodic drop in lake levels to water withdrawals for generation of hydropower at the second Kiira Dam in Uganda. This would mean a deviation from the operating rule known as the Agreed Curve of 1954, which is a best estimate of the rating curve of the lake outlet under natural conditions.

\section{River migration}

The migration of the Nyando River has been described by Millman (1973) as the most recent geomorphological event to occur in the Kano floodplains. According to him, the river once reached Lake Victoria by a more direct course than at present, flowing westwards through a series of swamps to share a common outlet with Nyamasaria River at Nam Thoe swamp, southeast of Kisumu City. In the last 60 years, the river channel has been migrating laterally in an eastward direction and today debouches into Lake Victoria through the Miruka swamp (Nyando Wetland), having been joined by numerous tributaries from the surrounding southern highlands (Figure 12). The river mouth has been quite dynamic, moving further southwards and then northwards in Nyakach Bay, leading to the development of a delta (bird's foot type). In the period 1950-1973, the river channel migrated 4,900 $\mathrm{m}$ in an eastward direction representing a lateral displacement rate of $213 \mathrm{~m} /$ year. During this period, the river mouth was displaced $1,300 \mathrm{~m}$ southwards to Kusa. In the period 1973-2008, the river had a maximum lateral displacement of $1,500 \mathrm{~m}$ at a rate of $42 \mathrm{~m} / \mathrm{year}$ in an easterly direction. The river mouth was displaced $3,000 \mathrm{~m}$ northwards and split into three channels to form the present delta.

The migration of Nyando River has been explained by natural processes and anthropogenic activities. Millman (1973) explained that the main reason why the river course changed its original course towards the Nam Thoe swamp in Kisumu, was because it was blocked by detritus material from small rivers flowing southwards from Nandi Escarpment to Winam Gulf of Lake Victoria. Similarly, changes in the lateral displace- 

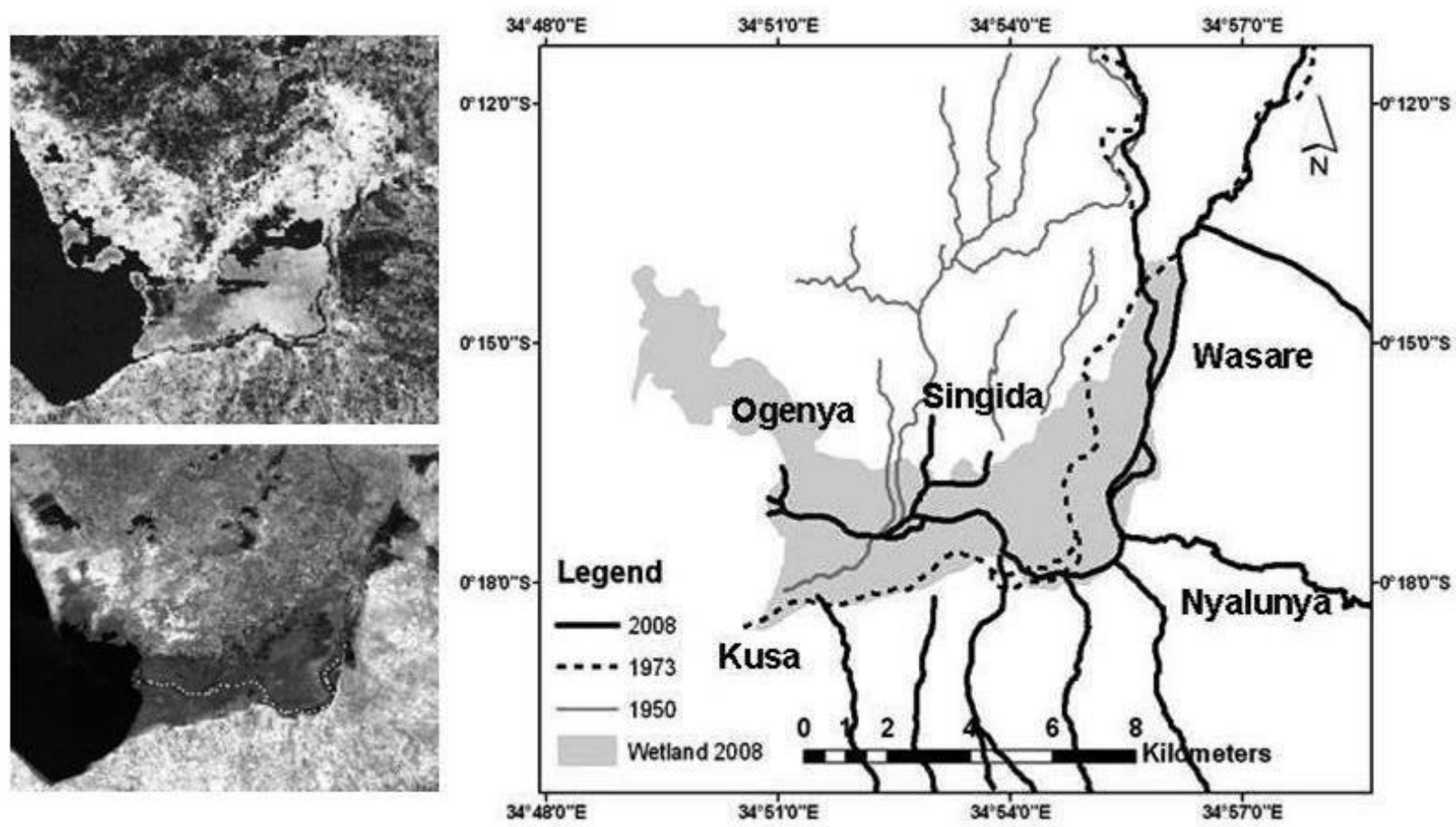

Figure 12. Landsat MSS imagery (Band 4) taken on $1^{\text {st }}$ February 1973 (top left panel), Landsat 5 ETM+ dated $28^{\text {th }}$ September 2008 (Band 5 with geo-referenced way points in small white dots) (bottom left panel) and polyline map showing the river migration patterns in the period 1950-2008 (right panel).

ment of the river course in the last 60 years is most probably due to deposition of excess sediment load carried by the river itself. The low gradient of the Kano floodplains and the river meanders have triggered deposition of sediments, leading to formation of several small islands, which block and force the river to split and finally change its course. The development of dykes and cut-off meanders to prevent persistent floods in 1975 (Ongwenyi et al., 1993) has limited lateral shift in the river course to within $4 \mathrm{~km}$ upstream of the delta. Instead the river channel has deepened 4 to $30 \mathrm{~km}$ from the delta as a result of increased conveyance capacity, leaving the wetland and adjacent floodplain decoupled from the river channel most of the time.

The most recent changes in river migration within the wetland area were related to changed land use activities and wildlife movements. According to the local community, the river exploited hippo trucks at Singida (Ligolo, personal comm.), and irrigation channels dug by Miruka at Wasare (Oliewo, personal comm.). The shift of the river mouth from Kusa Beach was linked to the blockage of the river channel by communities to prevent it from moving further south (Odhiambo, personal comm.). Historically, the migration of the Nyando River has been a major cause of conflicts between Nyakach and Kano communities, mainly because of loss or gain of land depending on which side of the bank is displaced. The Nyando River course and its main paleochannel,
Miriu are still used today as administrative boundaries of Nyakach, Nyando and Kisumu East districts.

\section{Wetland spatial and temporal changes}

In the past 60 years, the Nyando Wetland has undergone drastic changes in its size (Figure 13). The most prominent spatial changes have taken place in a 5 to $10 \mathrm{~km}$ zone in the northern landward section (SingidaKochogo areas) of the wetland. The littoral zone (lakeward section) of the wetland at Ogenya has experienced minimum spatial change of 0.5 to $3 \mathrm{~km}$ along the shoreline. The southern and southeastern landward sections were affected along a $1 \mathrm{~km}$ strip. The wetland area rose from 5,925 ha in 1950 to 9,925 ha in 1973, and dropped to 4527 ha in 2001 and 4,212 ha in 2008. The wetland increased by $67.5 \%$ growth in area in 1950-1973 and declined by $40 \%$ in 1973-1986, representing a negative growth rate of $305 \mathrm{ha} / \mathrm{y}$. The wetland size reduced steadily by $24 \%$ from $1986-2001$ and $7 \%$ from 2001-2008. The flood and drawdown events prevalent in the Nyando Wetland present two scenarios of river-wetland and lake-wetland surface-water exchanges: (i) a connected phase where floodwaters link the river and lake to the wetland to make one hydrological unit, and (ii) an isolated phase during drawdown events when the river and lake are physically 

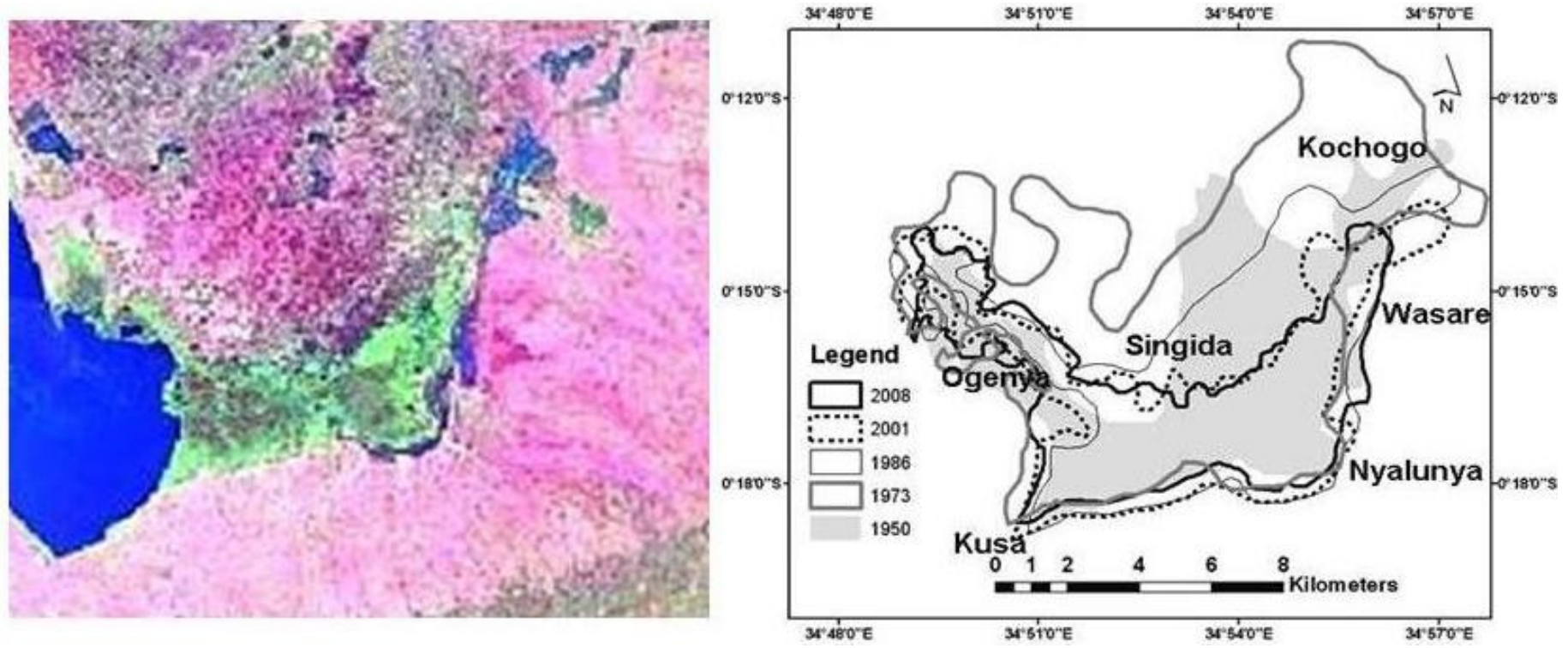

Figure 13. False colour composite of Landsat ETM+ taken on $28^{\text {th }}$ September 2008 showing Nyando Wetland (green), Lake Victoria (deep blue) and other land cover types (pink) (left panel) and multi-temporal polygon maps of Nyando Wetland in the period 1950-2008 (right panel).

separated from the adjacent wetland with no surface water or minimum exchanges respectively. Hydrological connectivity between the wetland and the surface water bodies is important for water supply to the wetland ecosystem. The rise of river and lake levels result in drowning of papyrus wetlands and flooding on the landward section that can transform new lands into a wetland (Kiwango and Wolanski, 2008). However, the drying out during a fall in the lake level, is also a significant source of mortality of papyrus (Mnaya and Wolanski, 2002; Kiwango and Wolanski, 2008).

Flooding facilitates not only exchanges of water, but also sediments and nutrients between the wetland and river/lake systems (Jenkins and Boulton, 2003), considered to be essential for the functioning and integrity of these systems (Lake et al., 2006). Conversely prolonged lack of lateral connectivity can result in considerable habitat loss (Boulton, 2003). The changes in wetland size respond to prevailing hydrological factors and anthropogenic activities. The increase in wetland size in 1950-1973 is attributed to the episodic large flood events experienced in the Lake Victoria region in 1961-64. During this period, the entire Lake Victoria (Millman, 1973) and Nyando River (Ongwenyi et al., 1993) were connected with Kano floodplains, as a single hydrological unit. According to Ongwenyi et al. (1993), the frequent overtopping of Nyando River resulted in the development of swamps in Kano floodplains. It is likely that the wetland size was bigger during the floods than captured by satellites in 1973. Historically, the papyrus dominated swamps were viewed as non-productive nuisance areas, and were better converted to agricultural use (Juma, 1989; Lake Basin Development Authority, 1989; Muthuri, 1989). Consequently, the Nyando and Ombeyi Wetlands were drained for the large-scale West Kano and Ahero Rice Irrigation Schemes, through a government initiative.

The decline in wetland size in 1973-1986 was influenced by several key factors; (i) modification of the Nyando River (ii) prolonged drought in the 1980s and (iii) the establishment of small-scale rice irrigation schemes. In 1975, dykes measuring $8 \mathrm{~km}$ in length were constructed along the river banks from Ahero downstream to prevent persistent floods (Ongwenyi et al., 1993). In addition, the river was trained (cut-off meanders) to increase its conveyance capacity. While these human activities prevented flooding and reduced property and human losses in the area adjacent to the dykes, the frequency and depth of floods and flood inundation patterns in the Nyando Wetland were drastically altered. The prolonged drought of early 1980s meant that the lateral connectivity of the wetland and river was lacking for a longer period. The situation was further exacerbated by the declining water table as evidenced by the drying up of shallow wells, most commonly used for potable water by riparian communities (DHV Consulting Engineering, 1988).

In the 1986-2001 period, patterns of land use changes and migrations in the Nyando Wetland had emerged (Figure 14). The papyrus loss increased with further conversion of the wetland to rain-fed agriculture and expansion of small-scale irrigation schemes, livestock grazing and settlements. The drainage and 


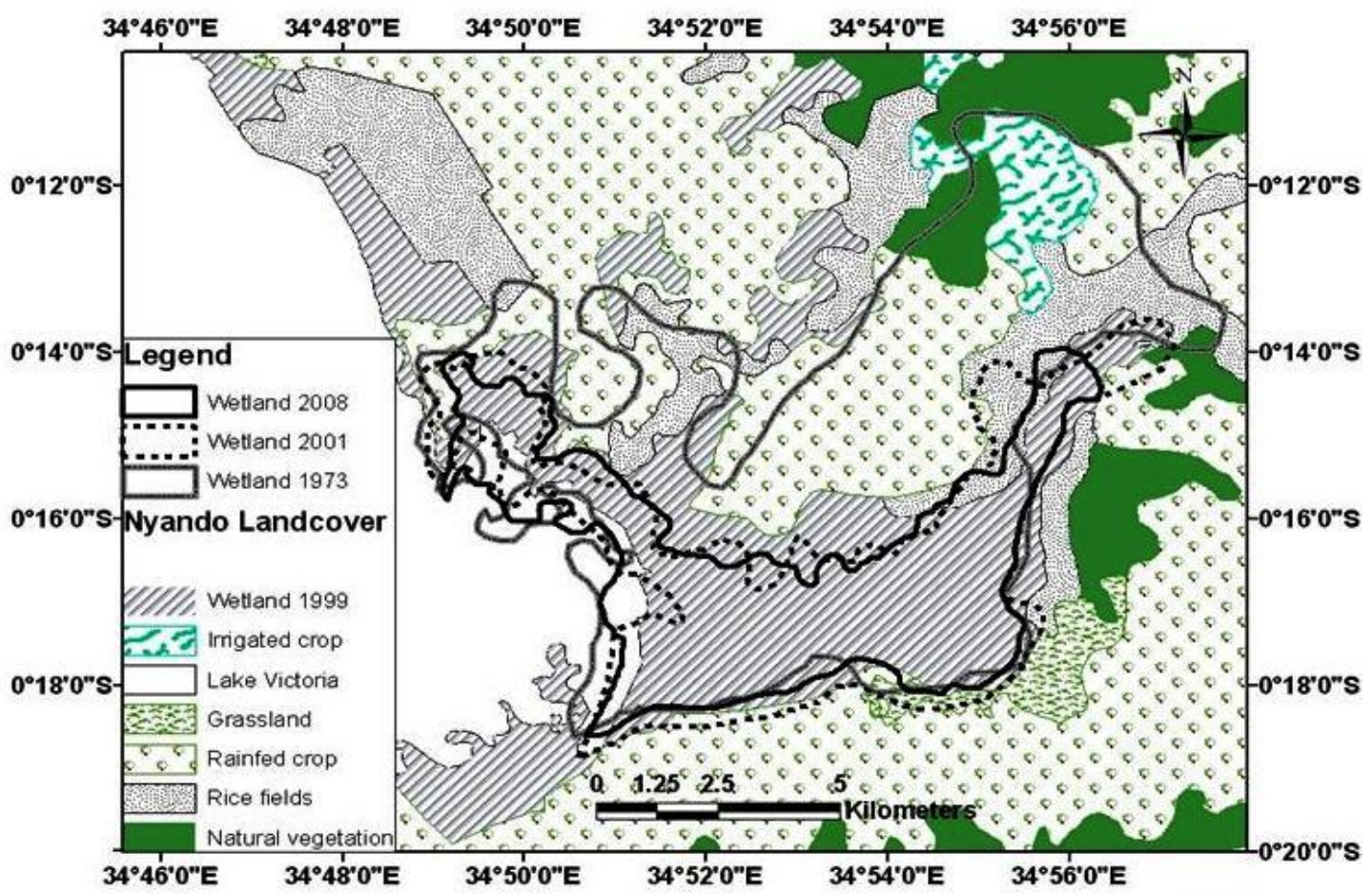

Figure 14. Land use and land cover (LULC) map of Nyando Wetland and its surrounding area in 1999, in relation to the wetland area coverage in 1973, 2001 and 2008 (source land use map: Afri-Cover 1999).

cultivation of papyrus swamps had intensified around the Kenyan part of Lake Victoria (Juma, 1989). The loss of papyrus in the landward and lakeward (littoral zone) sections, and riparian corridor occur quite sequentially. The process starts with the decline in lake and river levels making most parts of the wetland accessible for agricultural activities, livestock grazing and settlement. A combination of these factors decreases the overall rate of germination of papyrus and the opened fields become permanent and are expanded over time (Owino and Ryan, 2007). In this way, C. papyrus loses its key ecological functions (Harper and Mavuti, 2004) as they become more accessible for further clearance and animal trampling and livestock grazing. When episodic floods prevail, like the one that happened during the El Niño rains of 1996-1998, human activities in the wetland are abandoned and communities migrate to higher ground, giving room to papyrus to quickly re-generate.

With persistent perennial floods, the seasonal calendar of activities for riparian communities in the wetland environment was clearly defined. These patterns of papyrus destruction were observed in other papyrus dominated sites in Kenya (Harper and Mavuti, 2004, Owino and Ryan, 2007) and around Lake Victoria (Lung'aya, 2001; Kansiime et al., 2007; Kiwango and Wolanski, 2008).

In general, there were minimal land use changes in the wetland area in the period 2001 to 2008 . However, the wetland contracted on the southern landward section but extended on the lakeward section. The shift of the wetland towards the lake is likely due to the receding lake levels that result in exposure of the littoral zone. This may be related to the drastic drop in lake levels in recent times, mainly attributed to increased water withdrawal for generation of hydropower at the second Kiira Dam in Uganda (EAC, 2006; Kiwango and Wolanski, 2008). In addition, the expansion of the large-scale and small-scale rice irrigation schemes has increased water demand for irrigation and further altered the lateral connectivity of the wetland and river channel.

For example, the Ahero Pilot Irrigation Scheme pumps $544,081 \mathrm{~m}^{3} /$ day $\left(6.30 \mathrm{~m}^{3} / \mathrm{s}\right)$ directly from the river, which is more than the 60 year long-term 7-day minimum annual flow of $239,328 \mathrm{~m}^{3} /$ day $\left(2.77 \mathrm{~m}^{3} / \mathrm{s}\right)$ and the reserve of $138,240 \mathrm{~m}^{3} /$ day $\left(1.6 \mathrm{~m}^{3} / \mathrm{s}\right)$. The reserve is defined as the amount of discharge required to meet environmental flows and basic human needs. With the planned expansion of the scheme and coupled with the numerous irrigation diversions downstream, there is clear need to provide storage facilities to meet domestic, public and irrigation water requirements. This may be the reason why a multi-purpose dam has been proposed to be developed at Koru at the foothills of the Nandi Escarpment and Kano floodplains. The operation of the multi-purpose dam is likely to regulate 
the river flow and perhaps alter the hydrological functioning of the wetland. In general, the environmental impacts assessment studies to be carried out during the feasibility phases of any proposed upstream dams should assess the Nyando Wetland water requirements.

Field surveys revealed that the shoreline has been exposed at Kusa Beach and turned into a cultivation zone, while supporting several fish ponds. Similarly, the Nyando delta has translated lake ward and the fringing papyrus has been replaced by hippo grass along the rim of Nyakach bay and the riverine riparian zone. The hippo grass is targeted for fishing and livestock grazing, especially during the dry season. Papyrus on the landward section in Ogenya and Singida Beaches is fast being replaced by sugarcane plantations, while the left bank and portions of the right bank of Nyando River at Wasare and Nyalunya are now covered by invasive species, most probably originating from the catchment. In this way, the chances of papyrus to re-generate and grow to maturity are quite limited, while the fish breeding grounds are severely destroyed. As observed by other researchers (Kansiime and Nalubega, 1999; Awange and Ong'ang'a, 2006; Owino and Ryan, 2007; Kiwango and Wolanski, 2008), the exposed shoreline and riparian zones are quickly encroached for settlements, livestock grazing and cultivation.

\section{Conclusions}

This study has shown that the evolution of the Nyando Wetland is influenced by hydrological and anthropogenic factors. The wetland spatial and temporal changes respond to seasonal wet-dry cycles and occasional episodic flood and drought events as observed in many tropical wetlands. The expansion in wetland size was caused by the El Niño floods of early 1960s that resulted in the papyrus translating on the landward section. The steady decline in wetland size is linked to a combination of key factors including the occurrence of prominent droughts (especially early 1980s) and seasonal dry spells and land use and land cover changes. The main human factors are regulation of the lake levels, modification of the river, irrigation water demand from Nyando River, encroachment of the wetland for agricultural activities, settlements and livestock grazing activities. Migration of the Nyando River is attributed to the blockage of the channel by natural sediment depositional processes, exploitation of hippo trucks and human drainage channels in the wetland. If the human activities continue unabated, the decline in size of the Nyando Wetland is likely to increase, with serious hydrological, ecological and socio-economic consequences. With increasing population pressure, coupled by climate variability, the wetland may be massively converted to irrigated and rain- fed agriculture. Clearly, there is need for trade-offs between conservation efforts and socio-economic activities.

\section{ACKNOWLEDGEMENTS}

The research described here was funded by the Netherlands Ministry of Development Cooperation (DGIS) through the UNESCO-IHE Partnership Research Fund (UPaRF). It was carried out jointly with UNESCOIHE, University of Amsterdam, Egerton University, Water Resources Management Authority, and VIRED International in the framework of the Research Project 'Ecology of Livelihoods in East African Wetlands' (ECOLIVE). It has not been subjected to peer and/or policy review by DGIS, and, therefore, does not necessarily reflect the view of DGIS.

\section{REFERENCES}

Alexandersson H (1986). A Homogeneity Test Applied to Precipitation Test. 6:661-675.

Alexandersson $\mathrm{H}$, Moberg A (1997). Homogenization of Swedish temperature data Part 1 Homogeneity tests for linear trends. Int. J. Climatol. 17:25-34.

Ashagrie AG, de Laat PJM, de Wit MJM, Tu Min, Uhlenbrook S (2006). Detecting the influence of land use changes on discharges and floods in the Meuse River Basin - the predictive power of a ninety-year rainfall-runoff relation? Hydrol. Earth System Sci. 10:111

Awange E JL, Ogalo L, Bae KH, Were P, Omondi $\mathrm{P}$, Omute $\mathrm{P}$, Omullo M (2008). Falling Lake Victoria water levels: Is climate a contributing factor? Clim. Change 89:281-297.

Awange JL, Aluoch J, Ogallo L, Omulo M, Omondi P (2007b). An assessment of frequency and severity of drought in the Lake Victoria region (Kenya) and its impact on food security. Climate Res 33:135-142.

Awange JL, Ong'ang'a O (2006). Lake Victoria ecology, resources and environment. Springer, Berlin. pp. 243-257.

Ba MB, Nicholson SE (1998). Analysis of convective activity and its relationship to the rainfall over the Rift Valley lakes of East Africa during 1983-90 using the Metoesat infrared channel. J. Appl. Meteorol. 37: 1250-1264.

Balirwa JS (1995). The Lake Victoria environment: its fisheries and wetlands- a review. Wetlands Ecology and Management 3: 209-224.

Birkett C, Murtugudde R, Allan T (1999). Indian Ocean climate event brings floods to East Africa's lakes and the Sudd Marsh. Geophys. Res Lett. 26:1031-1034.

Boulton AJ (2003). Parallels and contrasts in the effects of drought on stream macroinvertebrate assemblages. Freshwater Biol. 48:1173-1185

Conway D (2002). Extreme rainfall events and lake level changes in East Africa: recent events and historical precedents. In The Eas African Great Lakes: Limnology, Palaeolimnology and Biodiversity.

Conway D, Hulme M (1993). Recent fluctuations in precipitation and runoff over the Nile sub-basins and their impact on main Nile discharge. Climatic Change. 25:127-151.

COWI (2002). Integrated water quality/limnology study for Lake Victoria, Final Report Part II: LVEMP, Dar es Salaam.

DHV Consulting Engineers (1988). Water Resources Survey and Survey training Program. Rural Water Supply and Sanitation Programme. Report on Winam, Nyakach, Muhoroni and Nyando Divisions.

EAC (East African Community) (2006). Lake Victoria Basin Commission. Special report on the decline of water levels of Lake Victoria. Arusha, Tanzania. 
Flohn $H$ (1987). East African rains of $1961 / 62$ and the abrupt change of the White Nile discharge. Paleoecology of Africa 18:3-18.

Flohn H, Fraedrich K (1966). The daily periodic circulation and distribution of rainfall over Lake Victoria. Meteorologische Rundschau 19:157-165.

Harper DM, Mavuti KM (2004). Lake Naivasha, Kenya: Ecohydrology to guide the management of a tropical protected area. Ecohydrol. Hydrobiol. 4:287-305.

Hughes CE, Binning GP, Willgoose GR (1998). Characterization of the hydrology of an estuarine wetland. J. Hydrol. 211:34-49.

Gichuki J, Dahdouh-Guebas F, Mugo J, Rabuor CO, Triest L, Dehairs F (2001). Species inventory and the local uses of the plants and fishes of Lower Sondu Miriu wetland of Lake Victoria, Kenya. Hydrobiolgia 458:99-106.

Gopal B, Junk WJ (2000). Biodiversity in wetlands: an introduction. In: Gopal B, Junk WJ, Davies JA (eds) Biodiversity in wetlands: assessment, function and conservation. Backhuys, Leiden, pp. 1-10.

Greeson PE., Clark JR, Clark JE (1979). Wetland Functions and Values: the State of our Understanding. American Water Resources Association. Minnepolis, MN, USA.

Jenkins K, Boulton AJ (2003). Connectivity in a Dryland River: ShortTerm Aquatic Microinvertebrate Recruitment Following Floodplain Inundation Ecol. 84:2708- 2723.

Jones MB, Muthuri FM (1984). The diurnal course of plant water potential, stomtal conductance and transpiration in a papyrus (Cyperus papyrus L.) canopy. Oecologia 63:252-255.

Juma C (1989). Public policy and the Yala Swamp. Resources 1:21-22.

Junk WJ, Bayley PB, Sparks RE (1989). The flood pulse concept in river-floodplain systems. Canadian Special Publication of Fisheries and Aquatic Sciences, Proceedings of the International Large River Symposium 106:110-27.

Kansiime F, Saunders MJ, LOISELLE SA (2007) Functioning and dynamics of wetland vegetation of Lake Victoria: an overview. Wetlands Ecol. Manage. 15:443- 445.

Kansiime F, Nalubega M (1999). Wastewater treatment by a natural wetland: the Nakivubo swamp, Uganda. Processes and implications. PhD Thesis, A.A. Balkema Publishers, Rotterdam, The Netherlands.

Kipkemboi J (2006). Finger ponds: seasonal integrated aquaculture In East African freshwater wetlands; Exploring their potential for wise use strategies. PhD Thesis UNESCO-IHE pp.1-4. Kite GW (1981). Recent changes in level of Lake Victoria. Hydrol. Sci. Bull. 26:233-243.

Kiwango YA, Wolanski E (2008). Papyrus wetlands, nutrients balance, fisheries collapse, food security, and Lake Victoria level decline in 2000-2006. Wetlands Ecol. Manage. 16:89-96.

Kiiza M, Rodhe A, Chong-Yu Xu, Ntale EHK, Halldin S (2009). Temporal rainfall variability in the Lake Victoria Basin in East Africa during the twentieth century. Theor. Appl. Climatol. 98:119-135.

Kull D (2006). Connections between recent water level drops in Lake Victoria, Dam operations and drought. http://www.irn.org/programs/nile/pdf/060208vic.pdf.

Lake S, Bond N, Reich P (2006). Floods Down Rivers: From Damaging to Replenishing Forces. Advances in Ecological Research, 39: 41-62.

Lake Basin Development Authority (1989). Reclaiming the Yala Swamp. Resources 1:9-12.

Lung'aiya H, Sitoki L, Kenyanya M (2001). The nutrient enrichment of Lake Victoria (Kenyan waters). Hydrobiology 458:7582.

Macalister C, Mahaxay M (2009). Mapping wetlands in the Lower Mekong Basin for wetland resource and conservation management using Landsat ETM images and field survey data. J. Environ. Manage. 90:2130-2137.

MacLean IMD (2004). An ecological and socio-economic of biodiversity conservation of East African wetlands. PhD Thesis, School of Environmental Sciences, University of East Anglia, Norwich, 210.

MacLean IMD, Tinch R, Hassal M, Boar R (2003). Towards optimal use of tropical wetlands: an economic valuation of goods derived from papyrus swamps in southwest Uganda. CSERGE W orking Paper ECM 03-10. University of Anglia, Norwich.

Mafabi $P$ (2000). The role of wetland policies in the conservation of water birds: the case of Uganda. Ostrich. 71:96-98.
Melack JM, Hess LL, Sippel S (1994). Remote sensing of lakes and floodplains in the Amazon Basin. Remote Sens. Rev. 10:127-142.

Millennium Ecosystem Assessment (2005). Ecosystems and human well-being: synthesis. Island Press, W ashington. p. 155.

Millman R (1973). Problems of the Natural Environment of the Kano Plains of Western Kenya. Description orographique, hydrologique et climatolique d'une region naturelle a proximite du lac Victoria (golfe du Kavirondo). 13(50):182-192.

Mistry VV, Conway D (2003). Remote forcing of east African rainfall and relationships with fluctuations in levels of Lake Victoria. int. J. Climatol. 23:67-89.

Mitsch WJ (2010). Conservation, restoration and creation of wetlands: a global perspective. In Comin, F. (ed.), Ecological Restoration: A Global Challenge. Cambridge University Press, Cambridge. pp. 175-188.

Mitsch WJ, Gosselink JG (1993). Wetlands, $2^{\text {nd }}$ ed. Van Nostrand Reinhold, New York.

Nicholson SE (1998). Historical fluctuations of Lake Victoria and other lakes in the Northern Rift valley of East Africa. In: Lehman JT (ed) Environmental Change and Response in East African Lakes. Kluwer, Dodrecht. pp.7-35

Mnaya B, Wolanski E, Kiwango Y (2006) Papyrus wetlands a lunar-modulated refuge for aquatic fauna. Wetlands Ecol. Manage. 14:359-363.

Muthuri FM, Jones MB, Mimbamba SK (1989). Primary productivity of papyrus Cyperus papyrus in a tropical swamp, Lake Naivasha, Kenya. Biomass 18:1-14.

Odada EO, Ochola WO, Olago DO (2009). Understanding future ecosystem changes in Lake Victoria basin using participatory local scenarios. Afr. J. Ecol. 47:147-153.

Ogallo LA (1993) Dynamics of the East African climate. Proc Indian Acad Sci (Earth Planet Sci.) 102:203-217

Ogallo L (1988) Relationships between seasonal rainfall in East Africa and the Southern Oscillation. J. Clim. 8:31-43.

Okeyo-Owuor JB (1999). A review of biodiversity and socioeconomics research in relation to fisheries in Lake Victoria. IUCN Eastern Africa Program, Nairobi. p. 77.

Ongwenyi GS, Denga FGO, Abwao P, Kitheka JU (1993). Impacts of floods and drought on the development of water resources of Kenya: case studies of Nyando and Tanacatchments. Hydrology of Warm Humid Regions (Proceedings of the Yokohama Symposium, July 1993). IAHS Publ. No. 216.

Osumba JJL, Okeyo-Owuor JB, Raburu PO (2010). Effect of harvesting on temporal papyrus (Cyperus papyrus) biomass regeneration potential among swamps in Winam Gulf wetlands of Lake Victoria Basin, Kenya. Wetlands Ecol. Manage. 18:333-341.

Owino AO and Ryan PG (2007). Recent papyrus swamp habitat loss and conservation implications in western Kenya. Wetlands Ecol. Manage. 15:1-12.

Perez AC, Damen MCJ, Geneletti D, Hobma TW (2001). Monitoring a recent delta formation in a tropical coastal wetland using remote sensing and GIS. Case Study: Guapo River Delta, Laguna de Tacarigua, Venezuela.

Pettit AN (1979). A non-parametric approach to the change-point detection. Appl. Stat. 28 126-135.

Richardson SM, Hanson JM, Locke A (2002). Effects of impoundment and water-level fl uctuations on macrophyte and macroinvertebrate communities of a dammed tidal river. Aquat. Ecol 36:493-510.

Saggerson EP (1947). The Geology of Kisumu District., Report no. 21, Nairobi.

Scheren PA, Zantingha, Lemmens AMC (2000). Estimation of water pollution sources in Lake Victoria, East Africa: application and elaboration of the rapid assessment methodology. J. Environ. Manage. 58:235-248.

Schuyt KD (2005). Economic consequences of wetland degradation for local populations in Africa. Ecol. Econ. 53:177-190.

Shakleton RM (1952). A contribution to the Geology of Kavirondo Rift Valley. Q. J. Meteorol. Soc. 196 (4).

Siegel S, Castellan NJ (1988). Non-parametric Statistics for the Behavioural Sciences. McGraw-Hill, New York, USA.

Uhlenbrook S (2009). Climate and man-made changes and their impacts on catchments. In: Kovar P., Maca P., Redinova J. (eds.). 
Water Policy 2009, Water as a Vulnerable and Exhaustible Resource. Proceedings of the Joint Conference of APLU and ICA, 23-26 June 2009, Prague, Czech Republic. pp. 81-87.

Uhlenbrook S (2007). Biofuel and water cycle dynamics: what are the related challenges for hydrological processes research? HP Today. Hydrol. Proc. 21(26):3647-3650.

Tu Min., Hal MJ, de Laat PJM, de Wit MJM (2004). . Hydrology: Science and Practice for $21^{\text {th }}$ century. 1:235-238.

USDA (United States Department of Agriculture) (2005). Low Water Levels Observed on Lake Victoria. Production Estimates and Crop Assessment Division, Foreign Agricultural Service, USDA.

van Dam AA, Kipkemboi J, Zaal F, Okeyo-Owuor JB (2011). The ecology of livelihoods in East African papyrus wetlands (ECOLIVE) DOI 10.1007/s11157-011-9255-6. Rev. Environ. Sci. Biotechnol.

van Dam A.A, Dardona P, Kelderman F, Kansiime F (2007). Simulation model for nitrogen retention in a papyrus wetland near Lake Victoria, Uganda (East Africa). Wetlands Ecol. Manage. 15:469-480.

van Geest GJ, Coops H, Roijackers RMM, Buijse AD, Schefer M (2005a). Succession of aquatic vegetation driven by reduced waterlevel fluctuations in floodplain lakes. J. Appl. Ecol. 42:251-260.
Walsh SJ, Cooper JW, von Essen IE, Gallager KR (1990). Image enhancement of Landsat Thematic Mapper data and GIS data integration for evaluation of resource characteristics. Photogram. Eng. Remote Sens. 56:1135-1141.

Waruru B, Njoroge C, Wanjogu S (2003). Biophysical baseline information for the Nyando catchment area: The soils of the Nyando catchment area Reconnaissance Soil Survey Report.

Weilhoeferi CL, Pan Y, Eppard S (2008). The effects of river floodwaters on floodplain wetland water quality and diatom assemblages. WETLANDS. 28(2):473-486.

Wilcox DA, Meeker JE (1991). Disturbance effects on aquatic vegetation in regulated and unregulated lakes in northern Minnesota. Can. J. Bot. 69:1542-1551.

WMO (1982). Hydrometeorological survey of the catchments of

Lake Victoria, Kyoga and Albert: project findings and recommendations. WMO/UNDP RAP/73/001, WHO, Geneva.

Yin X, Nicholson SE (2002). Interpreting annual rainfall from the levels of Lake Victoria. J. Hydrometeorol. 3:406-416. 